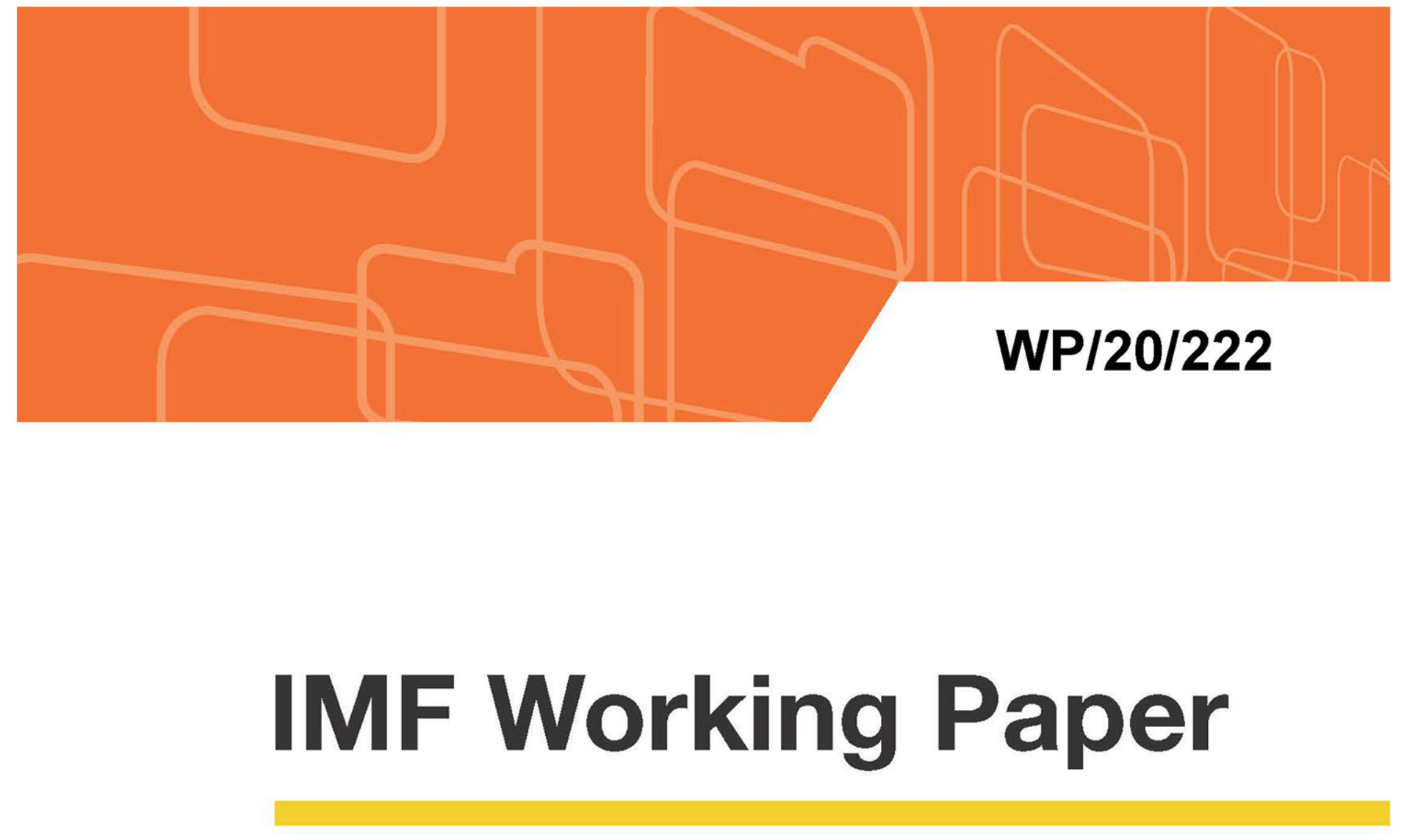

\title{
Mobile Phone Ownership and Welfare: Evidence from South Africa's Household Survey
}

by Ken Miyajima

IMF Working Papers describe research in progress by the author(s) and are published to elicit comments and to encourage debate. The views expressed in IMF Working Papers are those of the author(s) and do not necessarily represent the views of the IMF, its Executive Board, or IMF management. 


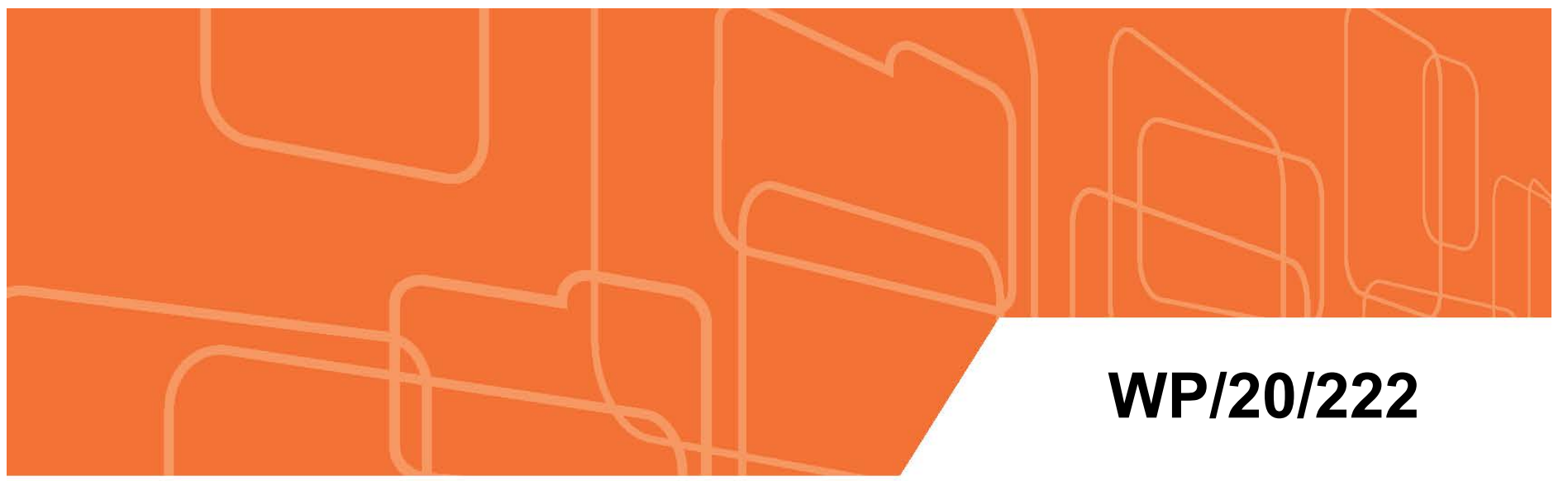

\section{IMF Working Paper}

\section{Mobile Phone Ownership and Welfare: Evidence from South Africa's Household Survey}

by Ken Miyajima

IMF Working Papers describe research in progress by the author(s) and are published to elicit comments and to encourage debate. The views expressed in IMF Working Papers are those of the author(s) and do not necessarily represent the views of the IMF, its Executive Board, or IMF management. 


\title{
IMF Working Paper
}

\author{
AFR \\ Mobile Phone Ownership and Welfare: Evidence from South Africa's Household Survey \\ Prepared by Ken Miyajima
}

Authorized for distribution by Ana Lucía Coronel

October 2020

IMF Working Papers describe research in progress by the author and are published to elicit comments and to encourage debate. The views expressed in IMF Working Papers are those of the author and do not necessarily represent the views of the IMF, its Executive Board, or IMF management.

\begin{abstract}
Digitalization is accelerating as countries fight against the COVID-19 pandemic. In this context, the impact of mobile phone ownership on welfare (represented by consumption) is estimated for South Africa using rich household survey data in a panel format, the National Income Dynamics Study (NIDS) with 5 waves spanning 2008-17. The literature argues mobile phone ownership facilitates greater and more affordable access to information and generate welfare gains. We attempt to disentangle the two-way relationship between consumption and mobile phone ownership, which is inherently difficult, and add to the literature by investigating distributional effects. Estimated results suggest that consumption of mobile phone owners tends to be 10-20 percent above that of non-owners. Benefits tend to accrue more on individuals with relatively low levels of consumption, potentially as a greater number of new users, likely with higher marginal positive effects on consumption, and a faster rate of user cost reduction help reap greater gains.
\end{abstract}

JEL Classification Numbers: D15, O12, O55

Keywords: Digitalization, Household Survey, Instrumental Variable Approach, Mobile Phone, South Africa

Author's E-Mail Address: kmiyajima@,imf.org 


\section{CONTENT}

ABSTRACT__ $\underline{2}$

I. INTRODUCTION__

II. DIGITALIZATION AND FINANCIAL INCLUSION IN SOUTH AFRICA __ $\underline{\underline{5}}$

III. RELATED LITERATURE __ $\underline{8}$

IV. METHODOLOGY AND DATA _ _

A. Methodology

B. Data

V. RESULTS _ 13

A. Instrumenting Mobile Phone Ownership ___

B. Baseline Regressions

C. Distributional Effects

D. Potential Channels _ 19

VI. SUMMARY AND DISCUSSION __ $\underline{19}$

VII. REFERECES___

FIGURES

1. Indicators of Financial Inclusion in 2017

2. South Africa: Mobile Phone Ownership and Costs __

3. South Africa: Indicators of Mobile Phone __

4. Instrumented Mobile Phone Ownership __ 14

5. Consumption Impact of Mobile Phone Ownership by Consumption Decile ___ 17

\section{TABLES}

1. Real Consumption Level by Decile ___ 11

2. Individual Characteristics __ 12

3. Mobile Phone Ownership _ 13

4. Determinants of Mobile Phone Ownership___ 13

5. Determinants of Consumption in South Africa: Baseline Results __

6. Determinants of Consumption in South Africa: Distributional Effects ___

\section{ANNEX}

I. Tables and Figures 


\section{INTRODUCTION ${ }^{1}$}

South Africa's private consumption stagnated in the last decade amid weakening social indicators. On the back of strong economic growth, per-capita real private consumption started to rise in the mid-1990s, followed by impressive gains. Amid robust economic growth, which averaged above 4 percent year on year during 2000-08, the unemployment rate declined by more than 5 percentage points to 23 percent in 2008 . However, partly due to structural constraints, the growth momentum tapered off in the 2010s and per-capita private consumption started to stagnate (Figure A1 in the annex). The unemployment rate increased to 29 percent by 2019, with elevated levels among the youth. The share of those not in employment, education, or training (NEET) is high (Figure A2). South Africa's inequality, measured by the Gini coefficient, is one of the highest globally, reflecting a concentration of income among the highest 20th percentile (Figure A3). Social grants have a progressive impact on income distribution as they are an important and relatively steady source of income for lower income households. However, social grants do not substitute the private sector-led job creation needed to employ an expanding labor force (Figure A4). Private consumption is set to weaken substantially amid the COVID-19 pandemic.

On the upside, the ongoing advancement of digitalization and fintech may have helped improve consumer welfare in South Africa. The nation's fintech industry, including the large telecom companies ${ }^{2}$, is relatively large and growing, and the authorities are actively supporting its development while mitigating potential risks. Reports suggest that during the COVID-19 pandemic, the government and businesses have stepped up the use of fintech with a variety of applications and IT initiatives to help the population maintain health and safety. For instance, broadband spectrum was released on a temporary basis and some sites were zero-rated. ${ }^{3}$ One important tool is the mobile phone-its ownership in South Africa has risen, particularly among the less affluent, and descriptive data analysis suggests that mobile phone ownership is associated with welfare gains, represented by consumption (Section II). This is consistent with findings in the literature on benefits from mobile phone usage in various countries through different channels - using a mobile phone helps save on travel time and

\footnotetext{
${ }^{1}$ The author is grateful to Anrich Daseman, Arif Ismail (both from the South African Reserve Bank), Dino Lazaridis (from the Financial Sector Conduct Authority South Africa), staff from the National Treasury, colleagues in the IMF African Department (AFR) April 2020 Regional Economic Outlook Digitalization Chapter team, AFR's Research Advisory Group, participants in the AFR Financial and Monetary Network seminar, Majid Bazarbash, Ana Lucía Coronel, Amina Lahreche, Rodolfo Maino, Samuel Mann, Montie Mlachila, Joannes Mongardini, Aneta Radzikowski, Amadou Sy, and Vimal Thakoor, for their thoughtful comments and suggestions. Any errors are the author's responsibility.

${ }^{2}$ The nation's two large telecommunication companies, Vodacom and MTN, have positioned themselves as fintech firms. They have offered infrastructure for mobile phones and related financial services for several years.

${ }^{3}$ Zero-rating is the practice of providing internet access without financial cost under certain conditions, such as by permitting access to only certain websites or by subsidizing the service with advertising or by exempting certain websites from the data allowance.
} 
costs, facilitates greater and more affordable access to information, and enhances market efficiency, among others (Section III).

Against this backdrop, this paper studies the impact of mobile phone ownership on individuals' consumption in South Africa. It contributes to the literature in several ways. It is one of the first studies to formally analyze the initial impact of fintech in South Africa, particularly by teasing out distributional effects across the consumption distribution. In contrast to many studies in African countries, which focus on the use of mobile money, this paper aims at capturing the impact of mobile phone ownership, which could come through a wider range of channels. This paper is also the first to leverage rich household survey data in South Africa, which track the same individuals (with unique IDs) across 5 waves spanning 2008-17, to assess the impact of digitalization. Results suggest that mobile phone ownership tends to lead to higher consumption, particularly among users with relatively low levels of consumption. One interpretation is that a greater number of new users and a faster pace of reduction of user costs help them reap greater gains. Policies to promote greater inclusion of lower income consumers into digitalization could enhance welfare.

This paper is structured as follows. Section II discusses digitalization and mobile phone ownership in South Africa. Section III reviews the related literature. Section IV explains the methodology and data used. Section V discusses estimated results. Section VI concludes.

\section{Digitalization and FinanCial InCLUSion in SoUth AFRICA}

Digitalization and fintech is advancing in South Africa (Genesis et al. (2019), IMF (2019)). Fintech start-ups are emerging across a wide range of services, with payment-related ones being the most popular. Services, including real-time clearing, contactless cards, and an interoperable card payment system were introduced relatively early compared to other emerging economies and have been used widely. The fintech data collection initiative, currently work in progress, will, when established, support compilation of data on fintech activity. ${ }^{4}$ The emergence of fintech has been supported by policymakers and regulators. Fintech activity, including products outside of payment services, may require a regulatory review to ensure that regulations are commensurate with emerging innovations. Further reviews of how fintech activities fit in with emerging fintech innovation is underway and will be assessed continuously. An activity-based approach aims at ensuring level playing fields irrespective of the innovator being a fintech firm or not. For instance, South Africa was globally the first to introduce a regulatory sandbox where at least six regulators have collaborated to assess whether mobile payments akin to Kenya's M-PESA could operate. During the COVID-19 pandemic, the government has used WhatsApp to run an interactive chatbot to answer queries on COVID-19 and leveraging mobile phone location data.

Fintech has the potential to enhance financial inclusion (Alliance for Financial Inclusion (various years), Philippon (2020)). In South Africa, ample scope for greater financial

\footnotetext{
${ }^{4}$ The Hub aims at harmonizing the data approach. Data will be collected through a singular platform. Raw data and analysis will meet all legal requirements including on privacy and will be used across regulators. Where appropriate, exchanges, academia, and industries will have access.
} 
inclusion exists, particularly in terms of engagement (Figure 1). Access, measured by account holdings, is relatively high but South Africa performs less well in engagement or usage, with gaps along the gender, income, and social spectrums. Those lacking access cite high cost, long distance, and low trust as impediments. This is consistent with the view that the concentrated formal banking system charges relatively high fees, and that some of the legacies of apartheid persist - including spatial inequality (the poor live far from the center of economic activity) and low financial literacy associated with low educational attainment. Low trust may be related to the memory of price and financial instability, that is, high and volatile inflation prior to the introduction of inflation targeting in the early-2000s and episodes of bank failure in the early-2000s and mid-2010s (Havemann $(2018,2020)$ ), or to the fact that customers that are yet to establish relationship with banks, particularly the poor, perceive banks as access points only.

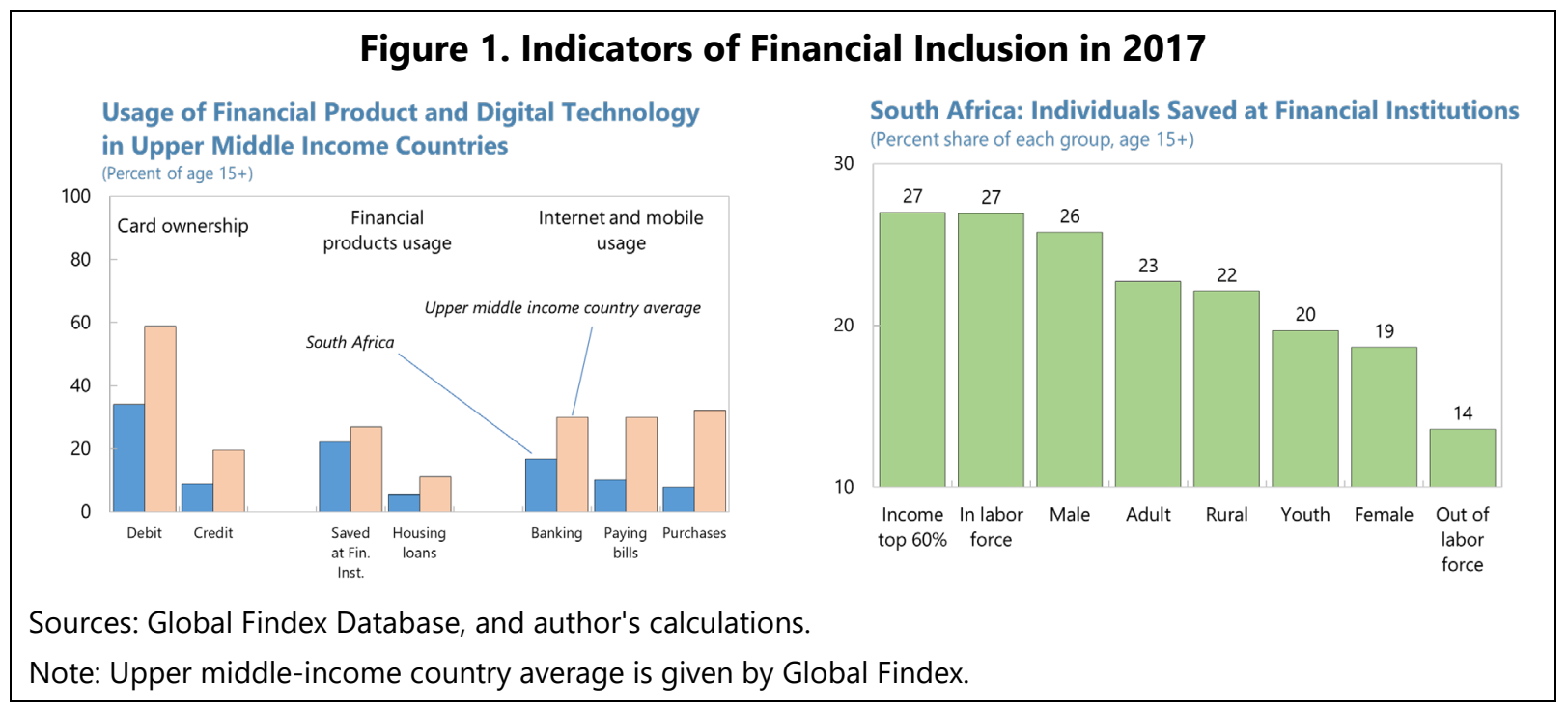

Figure 2. South Africa: Mobile Phone Ownership and Costs
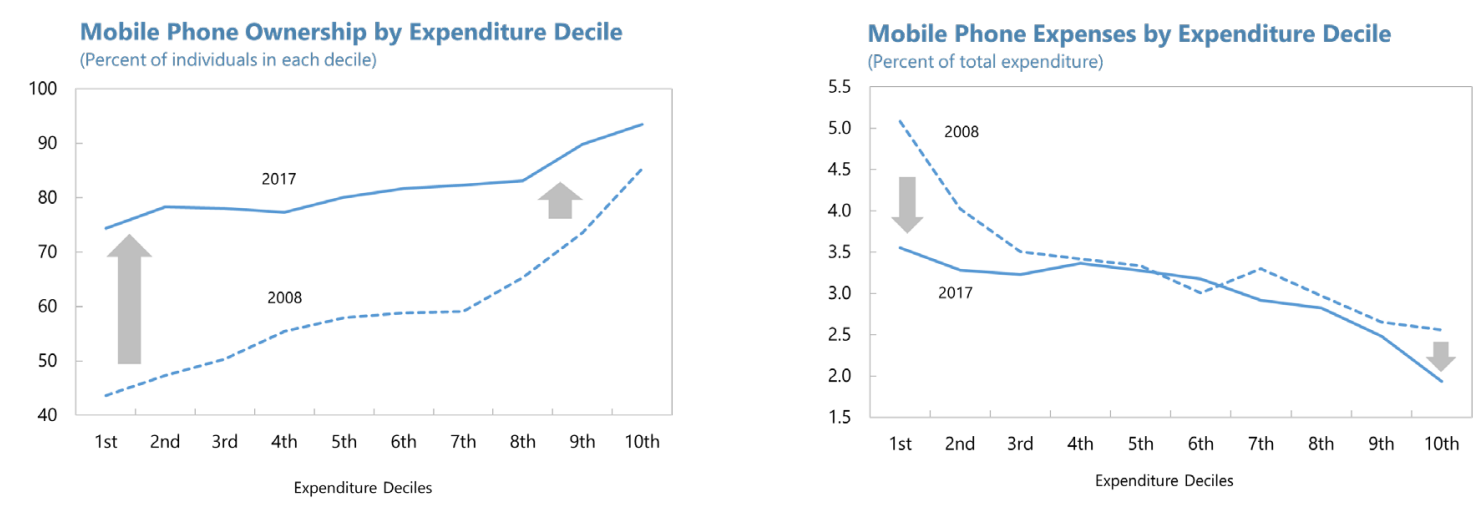

Sources: NIDS Waves 1 and 5, and author's calculations.

Among different types of access to finance, store cards are one of the most important for lower income households according to NIDS data. A few other media including personal bank loans and auto loans are also important. Home loans are more important for the better 
off. Extortionate informal loans, colloquially "mashonisa" loans, are often cited as important for lower income households, even though the amounts reported in NIDS represent a relatively small share of total loans drawn by lower income households. Mobile money, including remittances, is widely identified as a key channel in other parts of Africa (Jack and Suri (2014), Munyegera and Matsumoto (2016), Aron (2018)). NIDS data includes information on remittances but not specifically via a mobile phone (no information either on how a mobile phone is used).

As a key medium of digitalization and financial inclusion, mobile phone ownership rose and related expense declined, particularly among those at the lower end of the consumption distribution (Figure 2). Household survey data, discussed in detail in Section III, show that mobile phone ownership rose during the decade through 2017, particularly among the population in lower consumption deciles. For instance, for those in the lowest consumption decile, mobile phone ownership rose by 30 percentage points to 74 percent. During the same period, mobile phone-related expenses declined relative to users' total consumption, suggesting a fall in the unit cost of services, potentially allowing to use related services to a greater extent and reap more benefits from owning a mobile phone.

Figure 3. South Africa: Indicators of Mobile Phone
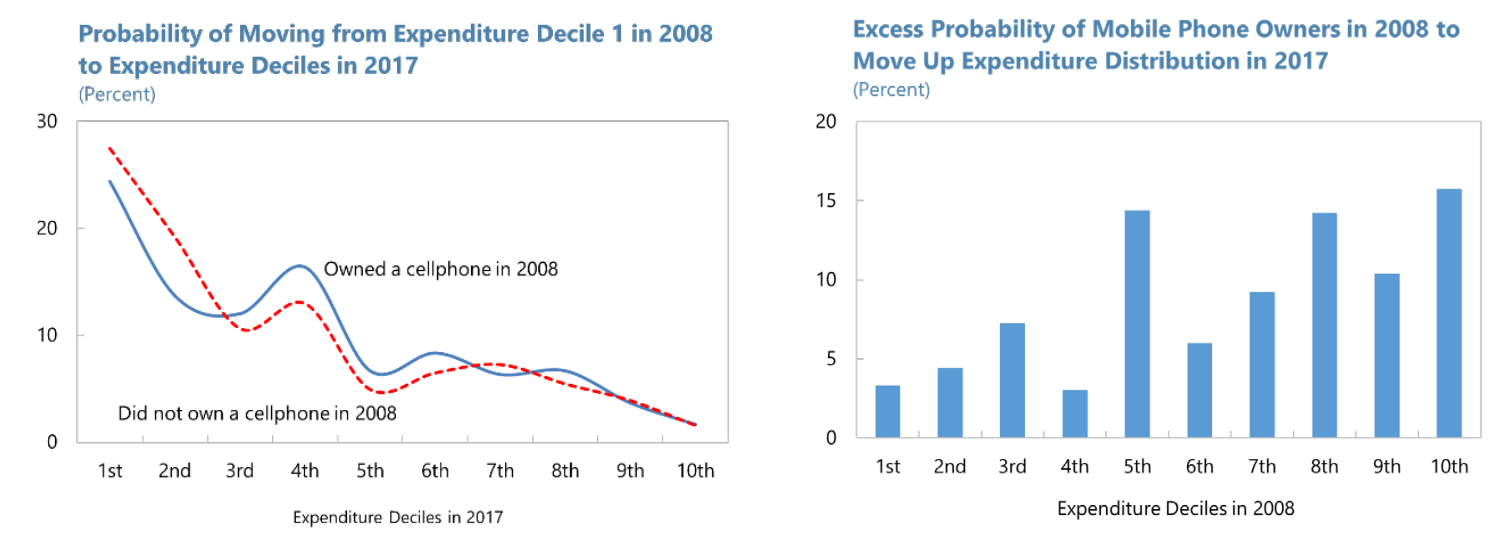

Sources: NIDS, and author's calculations.

Note: Excess probability represents conditional probability (on mobile phone ownership) differentials to unconditional probability of moving to higher consumption deciles. For $10^{\text {th }}$ decile, probability of remaining.

Tentative evidence suggests that mobile phone ownership is positively related with greater welfare in South Africa (Figure 3). As a way of measuring this relationship, the probabilities of moving to higher consumption deciles are compared between those with and without a mobile phone in 2008 (wave 1). ${ }^{5}$ The left panel of Figure 3 shows the two different probability distributions for the individuals in the first consumption decile in 2008 . The broken red line represents the probability for those without a mobile phone in 2008 of being in different consumption deciles in 2017 . The blue solid line represents such probability for

\footnotetext{
${ }^{5}$ By moving up to the next decile, consumption rises by around 30-40 percent on average, based on a narrower sample of population used for the econometric analysis later in the paper.
} 
those with a mobile phone in 2008. The difference between the sum of the area below the blue and red lines represents the "excess" probability of moving to higher consumption deciles (the area above the starting consumption decile is summed, as we are interested in the probability of moving up). For those in the first consumption decile in 2008 , the excess probability is 3 percent. The right panel displays the statistics across all 10 consumption deciles in 2008. Excess probabilities are positive across consumption deciles, suggesting that individuals who owned a mobile phone in 2008 were more likely to move up the consumption distribution by 2017 , relative to those without. The descriptive results could reflect either positive welfare effects of mobile phone ownership, or the fact that those with greater perceived chances of welfare gains in future tend to own a mobile phone. Moreover, some of the higher consumption of mobile phone users could reflect the spending associated with mobile phone usage (Figure 2).

\section{RELATED LITERATURE}

Results from surveys in Africa suggest that mobile phone ownership would increase welfare through different channels. According to World Bank (2016), in 12 African countries surveyed, 65 percent of individuals believe that their family members are better off because they own mobile phones (20 percent disagree, and 14.5 percent are not sure). Also, 73 percent of individuals argue that mobile phones help them save on travel time and costs (10 percent argue otherwise). Finally, two-thirds believe that having a mobile phone makes them feel safer and more secure.

The literature argues that mobile phone ownership facilitates greater and more affordable access to information, generating welfare gains (see, for instance, see Aker and Mbiti (2010) for an extensive survey for Africa). It enhances market efficiency (e.g., by sharing information on agricultural prices and labor markets), networking and starting a business, thus raising disposable income, particularly for the most vulnerable. Mobile phone usage enhances entrepreneurship and job search by reducing the costs of starting a business, information asymmetries, and market inefficiencies, and, in some instances, potentially substituting transportation (Bhavnani et al. (2008)). Market information allows farmers in the rural area to incorporate market and price considerations in their production, financial, investment and strategic decisions (Oyewumi (2006)). The adoption of mobile phones by fishermen and wholesalers led to a reduction in price dispersion, increasing both consumer and producer welfare (Jensen (2007)). Equal access to market information would reduce marketing costs, cut transportation expenses, and ensure fair transactions (De Silva (2005)).

Studies using household surveys find that mobile phone ownership would have positive welfare effects in Africa. A strand of literature focuses on mobile money. Often cited results by Jack and Suri (2014) using household survey data in Kenya suggest that M-PESA users' consumption is little affected by a negative shock, while nonusers' consumption suffers a 7 percent drop. Using household survey data in Uganda, Munyegera and Matsumoto (2016) find that mobile money users tend to have 13-20 percent higher consumption in different baskets over 3 years. However, after surveying a large volume of studies, Aron (2018) argues that mobile money fosters risk sharing but that direct evidence as to whether mobile money enhance welfare and savings is less robust. Studies using South African data are emerging, and Klonner and Nolen (2008) find that the rollout of a mobile phone network helped boost 
employment. Our study adds to the literature, focusing on South Africa, and assessing the impact of mobile phone ownership on individuals' consumption, paying attention to distributional effects.

In South Africa, mobile phones appear to represent a key medium for access to information, particularly among lower income earners. According to ICASA (2020), South Africa's mobile users increased, lifting smartphone penetration to over 90 percent in 2019. However, fixed broadband subscriptions dropped by almost 20 percent, particularly among lower income earners, as more users opted for wireless solutions or used the internet on their mobile phones.

The literature warns about risks from pursuing broader financial inclusion. In contrast to credit, other forms of access, such as basic payments and savings, do not adversely affect financial stability and can be promoted extensively, until their effects on growth fade (Sahay et al. 2015). Financial services are a powerful lever that can support a more inclusive society but, if not well managed, they can amplify inequalities (Čihák and Sahay, 2020).

Many studies attempt to addresses the inherently difficult issue of disentangling endogeneity between the dependent variable and usage or ownership of mobile money or phones. One common approach is to use pooled OLS and/or fixed effects panel approaches while instrumenting access to mobile money or phone by the distance to agents dealing mobile money or phone (Jack and Suri (2014), Munyegera and Matsumoto (2016, 2018), Tabetando and Matsumoto (2020), Riley (2018)). Another approach is to instrument household level mobile phone possession using interaction terms between the dummy variable for mobile phone coverage at the community level, which is time-variant, and initial household characteristics, which are time-invariant (Muto and Yamano (2009)). Similarly, Kikulwe, Fischer, and Qaim (2014) instrument household level mobile money usage by the proportion of households using mobile money or owning a mobile phone at the village level. Another commonly used approach is to rely on Generalized Method of Moments (GMM) proposed by Arellano and Bover (1995) and Blundell and Bond (1998) which is considered to be better at controlling for sources of endogeneity (e.g., unobserved heterogeneity, simultaneity, dynamic endogeneity). For instance, Aker (2010) uses the Arellano-Bond estimator to study the impact of mobile phone coverage on agricultural market performance in Niger.

Guided by the literature, this paper applies several approaches to help account for potential endogeneity between consumption and mobile phone ownership. First, the mobile phone ownership dummy is lagged to help reduce the chance of reverse causality. This also helps infer Granger causality - it does not identify causation and rather indicates if a variable can improve the prediction of the explanatory variable. Second, the mobile phone ownership dummy is instrumented by interaction terms between time-variant mobile phone ownership at the geographical level and time-invariant individual characteristics. Finally, system GMM proposed by Arellano and Bover (1995) and Blundell and Bond (1998) is applied. 


\section{Methodology ANd DAta}

\section{A. Methodology}

In our model, individual $i$ 's real consumption level in log in time $t, \ln c_{i, t}$ is regressed on an indicator of mobile phone ownership $m p h_{i, t}$ and a range of controls. Macro-level conditions are controlled for using real GDP level in $\log , \ln y_{i, t}$ and real policy rate, rpol $_{i, t}$ deflated by inflation expectations. Micro-level individual characteristics are controlled for using key determinants of resource availability that is, employment status, $e m p_{i, t}$. and educational attainment, $e d u_{i, t}$. Mobile phone ownership and other potentially endogenous control variables are lagged by one period to reduce the chance that results are affected by reverse causality and to help infer Granger causality. ${ }^{6}$ A lagged dependent variable, or the log of the real consumption level, is included to control for persistence and mean reversion. As inclusion of a lagged dependent variable biases coefficients (Nickell bias), regressions are estimated without a lagged dependent variable as well. Extreme values are removed by "winsorizing" the data.

In a bid to address a potential endogeneity issue, the mobile phone ownership dummy is instrumented by interaction terms between geography-level mobile phone ownership, which is time-variant, and individual characteristics, which is time-invariant (see Section V). Geography level mobile phone ownership is unlikely to be affected by individual level consumption. Individual characteristics are represented by population group (NIDS includes 4 groups), gender, and educational attainment (NIDS includes 5 groups) in wave 1.

We employ three different regression approaches_ pooled OLS (POOL), panel fixed effects (FE), and system GMM (GMM) approaches. POOL and FE are estimated with and without instrumenting the mobile phone ownership dummy. GMM is estimated using "raw" mobile phone ownership as the model includes its own instrumenting process. We follow Roodman (2007) to limit lag depth and "collapse" the matrix, or drop zeros from the instrument matrix, to help reduce the number of instruments and avoid over-fitting GMM models. An algebraic expression of the model for, for instance, a baseline FE model is as follows:

$$
\begin{aligned}
& \quad \begin{array}{l}
\ln c_{i, t}=a_{1} \operatorname{lnc}_{i, t-1}+a_{2} \operatorname{lny}_{t}+a_{3} r p o l_{t}+a_{4} m p h_{i, t-1}+a_{5} e m p_{i, t-1}+ \\
+a_{6, j} e d u_{i, t-1, j}+\alpha_{i}+c+\varepsilon_{i, t}
\end{array}
\end{aligned}
$$

Subscripts $i$ and $t$ signify individual and time. There are 5 levels of educational attainment $e d u_{i, t-1, j}(j=1, . ., 5) . \alpha_{i}$ is time invariant fixed effects of individual $i, c$ is constant, and $\varepsilon_{i, t}$ is the error term.

\footnotetext{
${ }^{6}$ The correlation between mobile phone ownership in $t$ and that in $t-1$ is 0.3 .

${ }^{7}$ At 10 th and 90 th percentiles.
} 


\section{B. Data}

The analysis relies on the National Income Dynamics Study (NIDS) data. NIDS is the first national household panel study in South Africa. It started in 2008 with a nationally representative sample of over 28,000 individuals in 7,300 households across the country. The survey is conducted approximately every two years, tracking same individuals with unique IDs. At present, five waves are available: 2008, 2010-11, 2012, 2014-15, and 2017. NIDS examines the livelihoods of individuals and households over time and provides information on a wide range of topics. ${ }^{8}$ The sample is restricted to the adults who are successfully surveyed across the 5 waves (about 6,900 adults). ${ }^{9}$

The dependent variable (individuals' real consumption level in log) is calculated as the overall consumption (food, non-food, and rental expenditures) of the household that the individual belongs to, divided by household size, and by the annual inflation index of the survey year. Individuals are surveyed in different years even in the same wave. Table 1 shows the real consumption level (not in log) after normalizing decile 1 in wave 1 equal to 100. From wave 1 to wave 5, real consumption rose at higher rates in middle deciles (50 percent or more cumulatively) than in high and low deciles (30-40 percent cumulatively). Relative to the first decile, consumption of the $5^{\text {th }}$ decile is $2.5-3$ times larger while that of the $9^{\text {th }}$ decile is $12-14$ times larger. By moving up to the next decile consumption tends to rise by 30-40 percent - the rates are higher at both ends of the consumption distribution.

\section{Table 1. Real Consumption Level by Decile}

(Normalized, decile 1 in wave $1=100$ )

\begin{tabular}{|c|c|c|c|c|c|c|c|c|c|}
\hline \multirow[b]{2}{*}{ Wave } & \multicolumn{9}{|c|}{ Consumption Decile } \\
\hline & 1 & 2 & 3 & 4 & 5 & 6 & 7 & 8 & 9 \\
\hline 1 & 100 & 135 & 170 & 211 & 262 & 329 & 431 & 638 & 1171 \\
\hline 2 & 87 & 122 & 155 & 191 & 243 & 311 & 427 & 619 & 1194 \\
\hline 3 & 96 & 129 & 171 & 220 & 280 & 369 & 503 & 765 & 1316 \\
\hline 4 & 120 & 166 & 216 & 275 & 356 & 461 & 615 & 904 & 1568 \\
\hline 5 & 130 & 179 & 236 & 306 & 387 & 506 & 658 & 934 & 1622 \\
\hline
\end{tabular}

Sources: NIDS and author's calculations.

The independent variables include both macroeconomic conditions and individual characteristics. Macroeconomic conditions are controlled for by real GDP level (in log) in the survey year. In addition, real GDP level is interacted with provincial dummies to capture time by location effects as standard in the literature. The mobile phone ownership dummy, either 1 or 0 , is created based on yes / no response. Questions pertaining mobile phone usage are not available. The employment dummy takes value of 1 when the individual is

\footnotetext{
${ }^{8}$ They include poverty, fertility, mortality, migration, labor market participation, economic activity, health, education, vulnerability, and social capital.

${ }^{9}$ Phone-based survey results were recently released as NIDS CRAM Wave 1 to help understand the impact of the COVID-19 pandemic. CRAM Wave 1 does not include some of the key variables used in the paper.
} 
"employed" and zero otherwise (either "not economically active", "unemployed strict", "unemployed discouraged", or "refused"). Indicators of educational attainment are created for 5 groups - no education (including “other" and “don't know”), lower primary (grades 1-7), upper primary (grades 8 and 9), secondary (grades 10-12, National Technical Certificate, and National Vocational Certificate), and tertiary (everything above secondary). Geography dummies are created for 4 types, rural and urban, both formal and informal (in equation $(1), j=1,2,3,4)$ for each survey year. The grant dummy takes value of 1 for recipients and 0 otherwise. Access to finance is proxied by store card ownership (one of the most important media for less affluent individuals), home loans, personal bank loans, micro lender loans, , mashonisa loans, and remittances.

Table 2 summarizes individual characteristics. As for the highest education level in wave 5, the share of primary level education is the highest (36 percent), followed by secondary (32 percent), tertiary (19 percent), and no schooling (13 percent). The share of tertiary rose by 12 points from wave 1, as those of primary and secondary declined. Around 40 percent of the sample are employed in wave 5, up 7 points from wave 1 . The data includes four population groups, "African", which represents the majority (84 percent), "Colored" (13 percent), "White" (2 percent), and "Asian/Indian" (1 percent). Female represent 68 percent of the sample. Geographically, most of the sample population reside in rural informal and urban formal areas (41 percent each in wave 5).

\begin{tabular}{|c|c|c|c|c|c|c|c|c|c|c|c|c|c|c|c|c|}
\hline \multicolumn{17}{|c|}{$\begin{array}{c}\text { Table 2. Individual Characteristics } \\
\text { (Percent) }\end{array}$} \\
\hline \multirow[b]{2}{*}{ Wave } & \multicolumn{5}{|c|}{ Education } & \multirow{2}{*}{$\frac{\text { Jobs }}{\text { Employed }}$} & \multicolumn{4}{|c|}{ Population group } & \multicolumn{2}{|c|}{ Gender } & \multicolumn{4}{|c|}{ Geography } \\
\hline & $\begin{array}{c}\text { No } \\
\text { Schooling }\end{array}$ & $\begin{array}{l}\text { Primary, } \\
\text { Lower }\end{array}$ & $\begin{array}{l}\text { Primary, } \\
\text { Upper }\end{array}$ & Secondary & $\begin{array}{l}\text { Tertiary } \\
\text { and up }\end{array}$ & & African & Colored & White & $\begin{array}{l}\text { Asian/ } \\
\text { Indian }\end{array}$ & Female & Male & $\begin{array}{l}\text { Rural, } \\
\text { Formal }\end{array}$ & $\begin{array}{c}\text { Rural, } \\
\text { Informal }\end{array}$ & $\begin{array}{l}\text { Urban, } \\
\text { Formal }\end{array}$ & $\begin{array}{l}\text { Urban, } \\
\text { Informal }\end{array}$ \\
\hline 1 & 12.7 & 27.4 & 18.1 & 34.4 & 7.4 & 38.1 & ... & $\ldots$ & $\ldots$ & $\ldots$ & $\ldots$ & $\ldots$ & 9.8 & 45.9 & 38.3 & 6.0 \\
\hline 2 & 13.1 & 24.5 & 16.3 & 36.2 & 9.9 & 32.7 & $\ldots$ & $\ldots$ & $\ldots$ & $\ldots$ & $\ldots$ & $\ldots$ & 10.2 & 44.9 & 38.6 & 6.0 \\
\hline 3 & 13.4 & 23.6 & 14.4 & 36.4 & 12.3 & 38.9 & $\ldots$ & $\ldots$ & $\ldots$ & & $\ldots$ & $\ldots$ & 10.1 & 43.4 & 40.0 & 6.5 \\
\hline 4 & 12.5 & 23.8 & 13.8 & 32.9 & 17.0 & 45.4 & ... & ... & $\ldots$ & & $\ldots$ & $\ldots$ & 10.2 & 42.0 & 41.0 & 6.8 \\
\hline 5 & 12.8 & 22.8 & 13.4 & 31.8 & 19.2 & 44.8 & $\ldots$ & $\ldots$ & $\ldots$ & $\ldots$ & $\ldots$ & $\ldots$ & 10.4 & 41.3 & 41.4 & 6.9 \\
\hline Average & 12.9 & 24.4 & 15.2 & 34.3 & 13.2 & 40.0 & 84.2 & 13.0 & 2.0 & 0.8 & 68.1 & 31.9 & 10.1 & 43.5 & 39.9 & 6.4 \\
\hline
\end{tabular}

Mobile phone ownership is associated with the individual characteristics as follows (Table 3 ). Mobile phone ownership rises with educational attainment, from no schooling (67 percent in wave 5) to primary education (around 80 percent), and secondary and tertiary (both around 90 percent). It is higher for those with a job ( 89 percent) than those without ( 78 percent); and for White (95 percent) and African (84 percent) than Asian/Indian and Colored (a little over 70 percent). The linkages along gender and geography are more mixed.

Combining a dependent variable that is estimated from household level response and explanatory variables based on individual level response may help address several issues. First, this could account for the potential externality where a mobile phone is used by multiple individuals in a household, which might be particularly the case at the lower end of the income distribution. If multiple household members reaped the benefits from a mobile phone owned by one household member, it would show in terms of higher overall household consumption. Second, the dependent variable would, to a lesser extent, systematically 
increase with mobile phone ownership through greater spending related to mobile phone usage, or access to finance through higher debt service requirements.

\begin{tabular}{|c|c|c|c|c|c|c|c|c|c|c|c|c|c|c|c|c|c|}
\hline \multirow[b]{3}{*}{ Wave } & \multicolumn{17}{|c|}{$\begin{array}{c}\text { Table 3. Mobile Phone Ownership } \\
\text { (Percent) }\end{array}$} \\
\hline & \multicolumn{5}{|c|}{ Education } & \multicolumn{2}{|c|}{ Jobs } & \multicolumn{4}{|c|}{ Population group } & \multicolumn{2}{|c|}{ Gender } & \multicolumn{4}{|c|}{ Geography } \\
\hline & $\begin{array}{l}\text { Tertiary } \\
\text { and up }\end{array}$ & Secondary & $\begin{array}{c}\text { Primary, } \\
\text { Upper }\end{array}$ & $\begin{array}{c}\text { Primary, } \\
\text { Lower }\end{array}$ & $\begin{array}{c}\text { No } \\
\text { Schooling }\end{array}$ & Employed & Unemp. & White & African & $\begin{array}{l}\text { Asian/ } \\
\text { Indian }\end{array}$ & Colored & Female & Male & $\begin{array}{l}\text { Urban, } \\
\text { Informal }\end{array}$ & $\begin{array}{l}\text { Urban, } \\
\text { Formal }\end{array}$ & $\begin{array}{c}\text { Rural, } \\
\text { Informal }\end{array}$ & $\begin{array}{l}\text { Rural, } \\
\text { Formal }\end{array}$ \\
\hline 1 & 90.0 & 71.5 & 54.4 & 49.6 & $\overline{43.3}$ & 73.1 & $\overline{52.8}$ & 78.2 & 61.9 & 52.5 & $\overline{48.9}$ & 61.3 & 59.0 & 66.2 & 65.3 & 56.7 & 56.1 \\
\hline 2 & 82.6 & 72.1 & 60.8 & 56.2 & 44.1 & 76.7 & 57.7 & 69.1 & 65.5 & 60.0 & 52.8 & 64.8 & 62.2 & 68.9 & 68.4 & 60.4 & 60.9 \\
\hline 3 & 95.1 & 89.4 & 81.3 & 75.1 & 66.9 & 89.6 & 78.2 & 92.7 & 84.5 & 85.0 & $\begin{array}{l}68.9 \\
68.9\end{array}$ & 82.5 & 83.4 & 83.7 & 84.1 & 83.2 & 76.3 \\
\hline 4 & 91.7 & 86.6 & 78.2 & 71.0 & 66.3 & 85.6 & 75.7 & 90.9 & 81.6 & 70.0 & 70.2 & 79.8 & 81.4 & 84.5 & 81.2 & 79.9 & 77. \\
\hline 5 & 91.3 & 88.0 & 81.2 & 76.5 & 66.7 & 88.5 & 77.5 & 94.6 & 83.9 & 72.5 & 71.8 & 82.2 & 83.4 & 81.6 & 82.8 & 83.0 & 78.8 \\
\hline Average & 90.1 & 81.5 & 71.2 & 65.7 & 57.5 & 82.7 & 68.4 & 85.1 & 75.5 & 68.0 & 62.5 & 74.1 & 73.9 & 77.0 & 76.4 & 72.6 & 69.8 \\
\hline
\end{tabular}

\section{RESUlts}

\section{A. Instrumenting Mobile Phone Ownership}

An instrumented variable (IV) is constructed for mobile phone ownership in a bid to further reduce the potential that it is affected by consumption on the left had side of the equation. Following Muto and Yamano (2009), it is conjectured that individuals with certain characteristics, such and higher educational attainment, are more likely to acquire mobile phones, and that it is more so when mobile phone ownership in the area they live is higher. It is also assumed that geography-level mobile phone ownership is less likely to be affected by individual-level consumption (or, the impact is smaller), and that individual-level timevariant choices, particularly consumption, does not influence time-invariant individual characteristics. With this in mind, the average mobile phone ownership by geography and wave, which is time-variant, is interacted with three sets of time-invariant individual characteristics - educational attainment in wave 1, population group, and gender. These characteristics appears to be correlated with mobile phone ownership (Table 3).

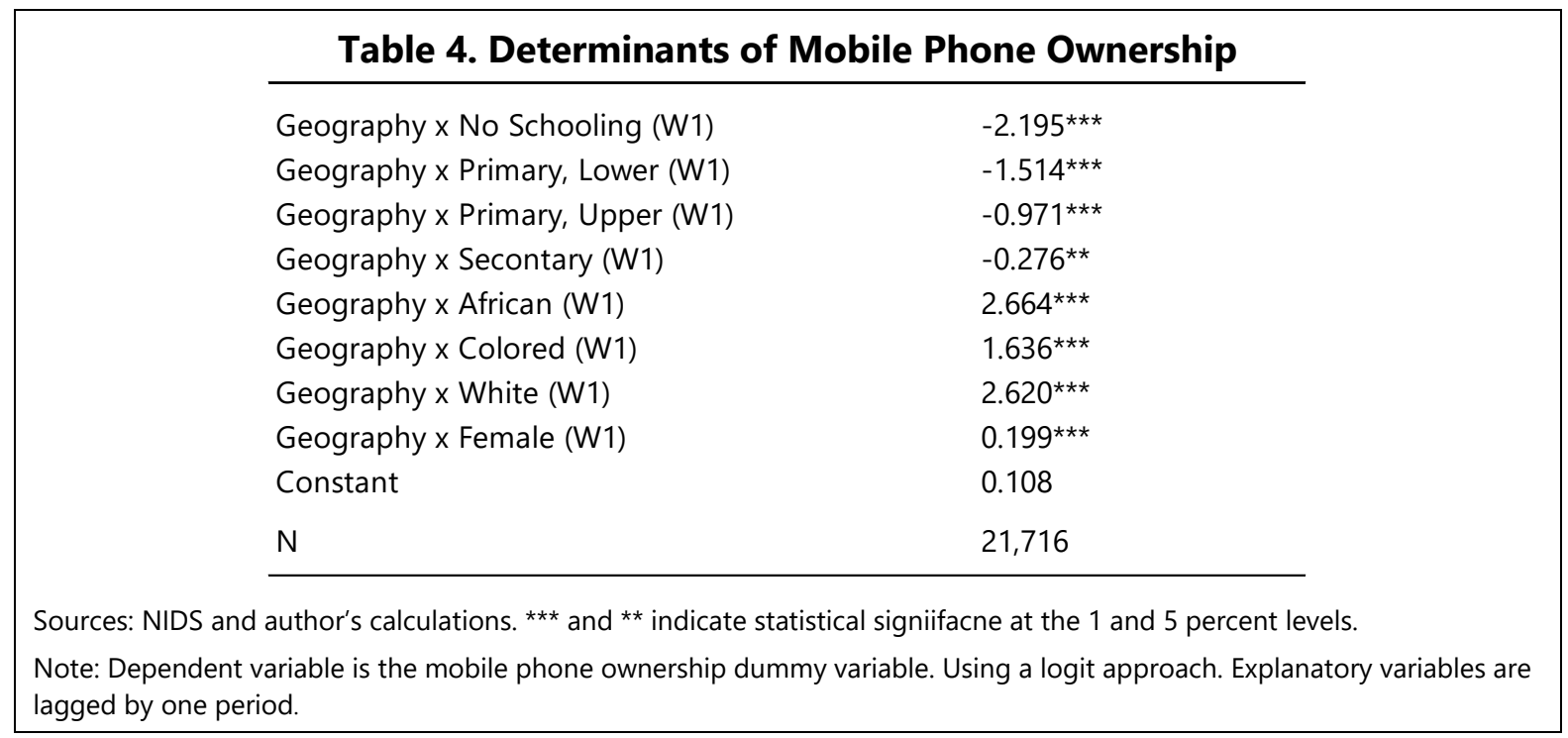


Estimated IV appears to reasonably capture actual mobile phone ownership. Results from logit regressions show that mobile phone ownership tend to be hither for individuals with higher initial educational attainment and those in certain population groups (Table 4). ${ }^{10}$ The regression results are in $\log$ odds ratio $p /(1+p)$ and converted into the probability of owning a mobile phone $p$ (Figure xx shows the distribution). Further, a value of 1 is assigned when $p$ is above a threshold $p^{*}$, where $p^{*}$ is set such that the number of ones in IV is equal to that in the original mobile phone ownership data. Estimated this way, $p^{*}$ is around 0.7 and ones in IV match a little over 80 percent of the original ones across waves 2-5 (IV is not available for wave 1 as explanatory variables are lagged by one period).

\section{Figure 4. Instrumented Mobile Phone Ownership}

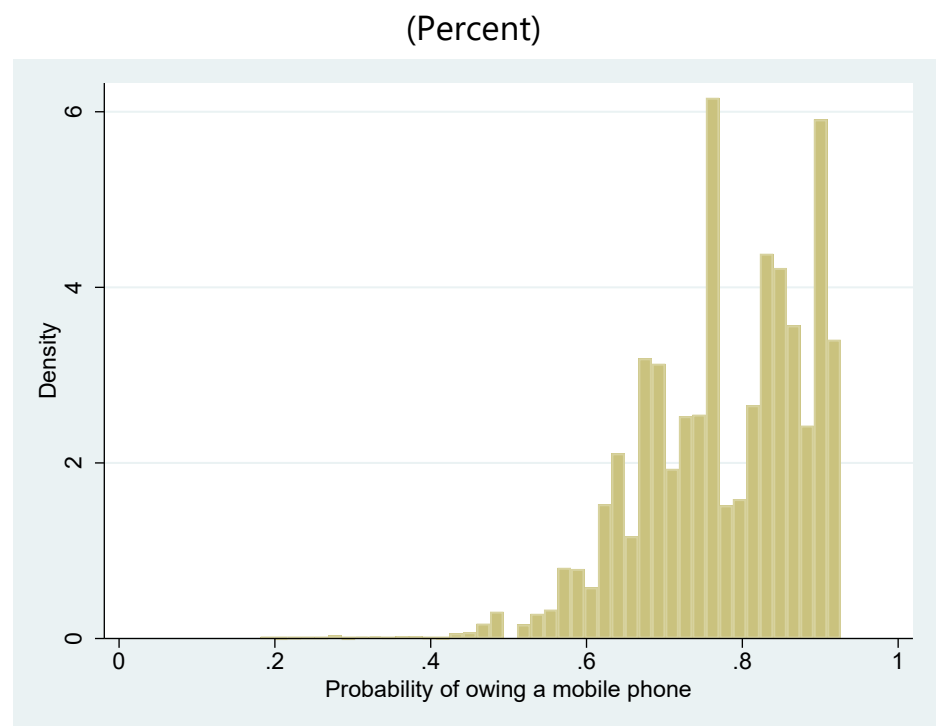

Sources: NIDS and author's calculations.

\section{B. Baseline Regressions}

Results from POOL, FE, and GMM suggest that mobile phone ownership is an important determinant of consumption, lifting owners' consumption by around 10-20 percent above that of those without a mobile phone (Table 5).

- Results from POOL with instrumented mobile phone ownership (POOL-IV) and lagged consumption suggest mobile phone owners tends consume 13 percent more than those without. The impact declines to 4 percent when "raw" ownership variable is used. When lagged consumption is dropped, the impact increases to close to 30 percent in POOL-IV and 15 percent in POOL, respectively.

\footnotetext{
${ }^{10}$ Interaction terms for tertiary education, Asian/Indian, and male are omitted.
} 
- Results from FE with instrumented mobile phone ownership (FE-IV), with or without lagged consumption, suggest mobile phone owners tends consume 15 percent more than those without. When "raw" data are used, ownership has no impact on consumption.

- Results from GMM suggest a large impact of 25-35 percent. The three models shown use the same lag depth (third only) to instrument endogenous variables but vary in the type of equations used to instrument pre-determined variables (either level, difference, or both). They pass commonly used specification tests - the null hypotheses of both no second order serial correlation and exogenous instruments cannot be rejected (see Table A1 in the annex for results from GMM with other specifications). We consider the GMM results as useful robustness checks - the estimated effects appear large, particularly when compared with the findings in the literature, and our experiments suggest estimated coefficients using GMM are not very stable.

Other control variables are important determinants of consumption. A one percent increase in real GDP growth is associated with 1-2 percent increases in consumption according to GMM, while 3.5-4 percent according to FE-IV. Higher educational attainment helps lift consumption while estimated effects vary across different models - those without schooling tend to consume 20 percent (FE-IV) to 80 percent (GMM) less than those with tertiary education. Consumption depends on gender and population group (POOL, POOL-IV). Estimated effects of employment and monetary policy (real policy rate) are more mixed. Lagged consumption captures persistence (coefficients of around 0.5) in POOL and POOL-IV while mean reversion (around -0.1 to -0.2 ) in FE and FE-IV. Lagged consumption is statistically insignificant in GMM, thus falling between FE and POOL results as excepted. 


\begin{tabular}{|c|c|c|c|c|c|c|c|c|c|c|c|c|}
\hline & & POOL & POOL & POOL-IV & POOL-IV & $\mathrm{FE}$ & $\mathrm{FE}$ & FE-IV & FE-IV & GMM & GMM & GMM \\
\hline \multicolumn{13}{|l|}{ Macro } \\
\hline Real GDP (log) & LO & $1.895^{\star \star \star}$ & $1.922^{\star \star *}$ & $2.823^{* * *}$ & $3.065^{\star * *}$ & $2.582^{* \star *}$ & $2.521^{\star \star \star}$ & $3.836^{\star \star \star}$ & $3.672^{\star * *}$ & $1.497^{\star \star \star}$ & $1.574^{\star \star \star}$ & $1.501^{\star \star \star}$ \\
\hline Real policy rate & LO & $-0.047^{* * *}$ & -0.009 & $-0.079^{\star \star *}$ & $-0.049^{* *}$ & $0.029^{\star \star \star}$ & $0.019^{\star \star}$ & -0.006 & -0.022 & $-0.041^{\star \star \star}$ & $-0.045^{\star \star *}$ & $-0.039^{\star \star \star}$ \\
\hline \multicolumn{13}{|l|}{ Micro } \\
\hline Owns a mobile phone & L1 & $0.041^{* * *}$ & $0.147^{\star \star \star}$ & $0.130^{\star \star \star}$ & $0.285^{\star \star \star}$ & 0.019 & 0.009 & $0.154^{\star \star \star}$ & $0.151^{\star \star \star}$ & $0.307^{\star *}$ & $0.242^{\wedge}$ & $0.359^{\star *}$ \\
\hline Employed & L1 & $0.083^{* \star *}$ & $0.282^{\star \star \star}$ & $0.076^{* \star \star}$ & $0.287^{\star \star \star}$ & $0.050^{\star \star \star}$ & $0.027^{\wedge}$ & 0.015 & -0.029 & 0.345 & 0.314 & 0.38 \\
\hline \multicolumn{13}{|l|}{ Education } \\
\hline No schooling & L1 & $-0.443^{* * *}$ & $-0.816^{* \star *}$ & $-0.368^{* * *}$ & $-0.615^{\star \star *}$ & $-0.235^{* * *}$ & $-0.224^{\star *}$ & $-0.194^{*}$ & -0.176 & $-1.620^{\star \star *}$ & $-1.610^{* * *}$ & $-1.631^{* * *}$ \\
\hline Primary, lower & L1 & $-0.359^{\star * *}$ & $-0.675^{\star \star *}$ & $-0.360^{\star * *}$ & $-0.650^{* * *}$ & $-0.286^{\star * *}$ & $-0.275^{\star * *}$ & $-0.223^{* *}$ & $-0.198^{\star *}$ & -0.216 & -0.239 & -0.191 \\
\hline Primary, higher & L1 & $-0.307^{\star * *}$ & $-0.569^{* \star *}$ & $-0.306^{\star * *}$ & $-0.560^{* \star *}$ & $-0.216^{\star * *}$ & $-0.209^{* * *}$ & $-0.180^{\star *}$ & $-0.172^{*}$ & $-1.282^{* * *}$ & $-1.282^{\star * *}$ & $-1.282^{\star * *}$ \\
\hline Secondary & L1 & $-0.174^{\star * *}$ & $-0.360^{* * *}$ & $-0.177^{\star \star \star}$ & $-0.371^{\star \star *}$ & $-0.053^{*}$ & -0.043 & $-0.06^{\wedge}$ & -0.04 & $-0.588^{* * *}$ & $-0.589 * \star \star$ & $-0.587^{* * *}$ \\
\hline Tertiary & L1 & $\ldots$ & $\ldots$ & $\ldots$ & $\ldots$ & $\ldots$ & $\ldots$ & $\ldots$ & $\ldots$ & $\ldots$ & $\ldots$ & $\ldots$ \\
\hline \multicolumn{13}{|l|}{ Population group } \\
\hline African & L1 & $-0.458^{\star \star \star}$ & $-1.008^{\star * \star}$ & $-0.534^{\star * *}$ & $-1.219^{\star \star \star}$ & $\ldots$ & & $\ldots$ & $\ldots$ & & $\ldots$ & $\ldots$ \\
\hline Asian/Indian & L1 & $\ldots$ & & & $\ldots$ & $\ldots$ & & $\ldots$ & & & $\ldots$ & $\ldots$ \\
\hline Colored & L1 & $-0.330^{\star \star \star}$ & $-0.677^{\star * *}$ & $-0.397^{\star \star \star}$ & $-0.843^{\star * \star}$ & $\ldots$ & $\ldots$ & $\ldots$ & $\ldots$ & $\ldots$ & $\ldots$ & $\ldots$ \\
\hline White & L1 & -0.008 & 0.005 & $-0.121^{\star *}$ & $-0.246^{\star * *}$ & $\ldots$ & $\ldots$ & $\ldots$ & $\ldots$ & $\ldots$ & $\ldots$ & $\ldots$ \\
\hline \multicolumn{13}{|l|}{ Gender } \\
\hline Female & L1 & $-0.171^{\star * *}$ & $-0.306^{\star * *}$ & $-0.190^{* * *}$ & $-0.337^{\star * *}$ & $\ldots$ & $\ldots$ & $\ldots$ & $\ldots$ & $\ldots$ & $\ldots$ & $\ldots$ \\
\hline Male & L1 & $\ldots$ & $\ldots$ & $\ldots$ & $\ldots$ & $\ldots$ & $\ldots$ & $\ldots$ & $\ldots$ & $\ldots$ & $\ldots$ & $\ldots$ \\
\hline \multicolumn{13}{|l|}{ Other } \\
\hline Real consumption (log) & L1 & $0.512^{\star \star \star}$ & $\ldots$ & $0.503^{* * *}$ & $\ldots$ & $-0.102^{\star \star \star}$ & $\ldots$ & $-0.177^{\star \star \star}$ & $\ldots$ & 0.182 & 0.203 & 0.161 \\
\hline Individual effects & $\ldots$ & $\mathrm{N}$ & $\mathrm{N}$ & $\mathrm{N}$ & $\mathrm{N}$ & $\mathrm{Y}$ & $\mathrm{Y}$ & $\mathrm{Y}$ & $\mathrm{Y}$ & Y & Y & Y \\
\hline Constant & $\ldots$ & $\mathrm{Y}$ & $\mathrm{Y}$ & $\mathrm{Y}$ & $\mathrm{Y}$ & $\mathrm{Y}$ & $\mathrm{Y}$ & $\mathrm{Y}$ & $\mathrm{Y}$ & $\mathrm{Y}$ & $\mathrm{Y}$ & $\mathrm{Y}$ \\
\hline \# of Obs. & & 21,716 & 21,716 & 16,287 & 16,287 & 21,716 & 21,716 & 16,287 & 16,287 & 21,716 & 21,716 & 21,716 \\
\hline Cross section $(\mathrm{N})$ & & 5,429 & 5,429 & 5,429 & 5,429 & 5,429 & 5,429 & 5,429 & 5,429 & 5,429 & 5,429 & 5,429 \\
\hline Time series $(\mathrm{T})$ & & 4 & 4 & 3 & 3 & 4 & 4 & 3 & 3 & 4 & 4 & 4 \\
\hline Adjusted R2 & & 0.501 & 0.326 & 0.496 & 0.320 & 0.089 & 0.080 & 0.089 & 0.058 & $\ldots$ & $\ldots$ & $\ldots$ \\
\hline ar1 & & $\ldots$ & $\ldots$ & $\ldots$ & $\ldots$ & $\ldots$ & $\ldots$ & $\ldots$ & $\ldots$ & 0.000 & 0.000 & 0.000 \\
\hline $\mathrm{ar} 2$ & & $\ldots$ & $\ldots$ & $\ldots$ & $\ldots$ & $\ldots$ & $\ldots$ & $\ldots$ & $\ldots$ & 0.275 & 0.228 & 0.322 \\
\hline hansen & & $\ldots$ & $\ldots$ & $\ldots$ & $\ldots$ & $\ldots$ & $\ldots$ & $\ldots$ & $\ldots$ & 0.343 & 0.358 & 0.325 \\
\hline gmm lag & & $\ldots$ & $\ldots$ & $\ldots$ & $\ldots$ & $\ldots$ & $\ldots$ & $\ldots$ & $\ldots$ & 3,3 & 3,3 & 3,3 \\
\hline gmm equation & & $\ldots$ & $\ldots$ & $\ldots$ & $\ldots$ & $\ldots$ & $\ldots$ & $\ldots$ & $\ldots$ & both & both & both \\
\hline iv equation & & $\ldots$ & $\ldots$ & $\ldots$ & $\ldots$ & $\ldots$ & $\ldots$ & $\ldots$ & $\ldots$ & both & level & diff \\
\hline
\end{tabular}




\section{Distributional Effects}

The role of mobile phone ownership on consumption is further assessed by paying attention to potential distributional effects. For instance, individuals at the lower end of the consumption distribution may have benefitted more. Increases in mobile phone ownership are more pronounced among individuals with lower consumption, indicating larger shares of new owners who may experience greater marginal positive effects in terms of consumption. These individuals also witnessed greater declines in mobile phone-related spending relative to overall consumption, indicating lower unit cost (Section II). Benefits would also depend on the type of phones and services used. To assess distributional effects, the mobile phone ownership dummy is interacted with consumption decile dummies. Consumption decile dummies are separately controlled for.

For the analysis we use FE and FE-IV, with additional explanatory variables. Distributional effects are assessed in relative terms with respect the baseline results which may help attenuate the impact of Nickell bias on the interpretation of estimated results. Additional control variables include whether one receives grants or not, geography (rural and urban, formal and informal), and interaction of real GDP and geography.

Figure 5. Consumption Impact of Mobile Phone Ownership by Consumption Decile

$($ Scaled, baseline coefficient $=1)$

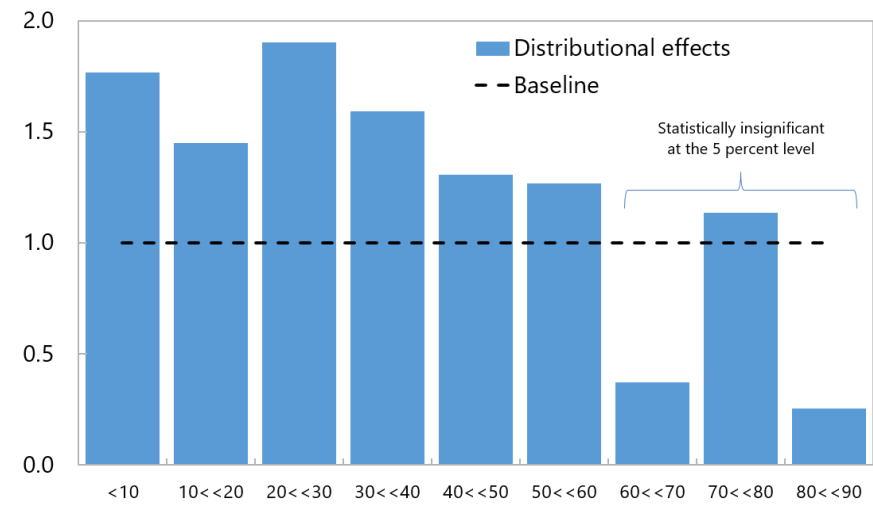

Sources: NIDS, and author's calculations.

Note: Showing FE-IV results, baseline and with distributional effects, with lagged real consumption.

Results suggest that the impact of mobile phone ownership on consumption remains significant, particularly among those in the lower part of the consumption distribution. Both FE and FE-IV models generate coefficients on interaction terms that are statistically significant and larger for lower consumption deciles (Table 6). To facilitate interpretation, Figure 5 plots the estimated coefficients from FE-IV with the lagged real consumption (results without the lagged real consumption are broadly similar), after being scaled such that the baseline coefficient is one. The coefficients for the first 6 consumption deciles are statistically significant at the 5 percent levels, and on average 55 percent larger than the baseline coefficient. 
Table 6. Determinants of Consumption in South Africa: Distributional Effects

\begin{tabular}{|c|c|c|c|c|c|}
\hline & & $\mathrm{FE}$ & $\mathrm{FE}$ & FE-IV & FE-IV \\
\hline \multicolumn{6}{|l|}{ Macro } \\
\hline Real GDP (log) & LO & $3.506^{\star * \star}$ & $3.370^{\star * *}$ & $3.752^{* * *}$ & $3.495^{\star * \star}$ \\
\hline Real policy rate & LO & 0.011 & -0.013 & 0.002 & -0.018 \\
\hline \multicolumn{6}{|l|}{ Micro } \\
\hline Owns a mobile phone & L1 & -0.064 & -0.072 & -0.074 & -0.096 \\
\hline \multicolumn{6}{|c|}{$\begin{array}{l}\text { Mobile phone ownership } \mathrm{x} \\
\text { consumption decile }\end{array}$} \\
\hline Ownership $x<10$ & L1 & $0.222^{* \star *}$ & $0.162^{* *}$ & $0.272^{* * *}$ & $0.295^{\star * *}$ \\
\hline Ownership x $10<<20$ & L1 & $0.163^{\star \star}$ & $0.151^{\star \star}$ & $0.223^{* *}$ & $0.246^{\star \star}$ \\
\hline Ownership $\times 20<<30$ & L1 & $0.202^{* *}$ & $0.178^{* *}$ & $0.293^{* * *}$ & $0.337^{\star * *}$ \\
\hline Ownership x $30<<40$ & L1 & $0.165^{\star \star}$ & $0.150 * *$ & $0.245^{\star \star}$ & $0.288^{* * *}$ \\
\hline Ownership $\times 40<<50$ & L1 & $0.117^{\star}$ & 0.102 & $0.201^{\star *}$ & $0.245^{\star \star}$ \\
\hline Ownership x $50<<60$ & L1 & 0.075 & 0.050 & $0.195^{\star \star}$ & $0.243^{\star *}$ \\
\hline Ownership x $60<<70$ & L1 & -0.034 & -0.028 & 0.057 & 0.075 \\
\hline Ownership x $70<<80$ & L1 & 0.120 & 0.104 & $0.175^{\star}$ & $0.193^{*}$ \\
\hline Ownership x $80<<90$ & L1 & 0.081 & 0.055 & 0.039 & 0.031 \\
\hline Employed & L1 & 0.001 & $-0.049 * * *$ & 0.002 & $-0.048^{\star * *}$ \\
\hline Receives grants & L1 & $-0.047^{\star \star}$ & -0.004 & $-0.046^{\star *}$ & -0.004 \\
\hline \multicolumn{6}{|l|}{ Education } \\
\hline No schooling & L1 & -0.142 & -0.129 & -0.144 & -0.126 \\
\hline Primary, lower & L1 & $-0.194^{\star *}$ & $-0.164^{*}$ & $-0.188^{* *}$ & $-0.156^{\star}$ \\
\hline Primary, higher & L1 & $-0.167^{\star}$ & $-0.156^{\star}$ & $-0.166^{\star}$ & $-0.152^{\star}$ \\
\hline Secondary & L1 & $-0.073^{* *}$ & -0.047 & $-0.074^{\star *}$ & -0.049 \\
\hline Tertiary & L1 & $\ldots$ & $\ldots$ & $\ldots$ & $\ldots$ \\
\hline \multicolumn{6}{|l|}{ Geography } \\
\hline Rural, formal & L1 & 0.062 & 0.043 & 0.064 & 0.045 \\
\hline Rural, informal & L1 & $-0.581^{\star \star *}$ & $-0.594^{* * *}$ & $-0.578^{\star \star \star}$ & $-0.589 * * *$ \\
\hline Urban, formal & L1 & $0.117^{\star \star *}$ & $0.112^{*}$ & $0.121^{* *}$ & $0.116^{\star \star}$ \\
\hline Urban, informal & L1 & $\ldots$ & $\ldots$ & $\ldots$ & $\ldots$ \\
\hline \multicolumn{6}{|l|}{ Other } \\
\hline Real consumption (log) & L1 & $-0.257^{\star \star \star}$ & $\ldots$ & $-0.250 * \star \star$ & $\ldots$ \\
\hline Consumption deciles & L1 & Y & $\mathrm{Y}$ & $\mathrm{Y}$ & $\mathrm{Y}$ \\
\hline Geography * GDP & L1 & $\mathrm{Y}$ & $\mathrm{Y}$ & $\mathrm{Y}$ & $\mathrm{Y}$ \\
\hline Weights & $\ldots$ & $\mathrm{Y}$ & Y & Y & $\mathrm{Y}$ \\
\hline Individual effects & $\ldots$ & Y & $\mathrm{Y}$ & Y & $\mathrm{Y}$ \\
\hline Constant & $\ldots$ & $\mathrm{Y}$ & Y & Y & Y \\
\hline \# of Obs. & & 16287 & 16287 & 16287 & 16287 \\
\hline Cross section (N) & & 5429 & 5429 & 5429 & 5429 \\
\hline Time series $(T)$ & & 3 & 3 & 3 & 3 \\
\hline Adjusted R2 & & 0.201 & 0.143 & 0.199 & 0.144 \\
\hline
\end{tabular}

Sources: Haver, NIDS, and author's calculations.

Note: Dependent variable is individual level real expenditure in log. L0 and L1 signify contemporaneous value and one period lag. $* * *, * *$, and * when statistically significant at the 1,5 , and 10 percent levels. FE-IV when instrumented mobile phone ownership is used. 
Other key determinants remain significant. The impact of real GDP is little changed, at around 3-4 percent. The real policy rates does not longer exert statistically significant effects. Effects of educational attainment are comparable to baseline results. Grant recipients tend to consume less than non-recipients, when the lagged consumption is included. Estimated coefficients on the employed is negative when the lagged consumption (the coefficients of which are negative) is excluded, seemingly capturing some of the impact of the lagged consumption. Comparing the urban population, those in formal areas tend to consume around 10-15 percent more than those in informal areas. Among those living in informal areas, the rural population tends to consume around 50-60 percent less than the urban population.

\section{Potential Channels}

Further attempt to tease out the potential channels through which mobile phone ownership supports consumption did not yield strong results (Annex Tables A2-A3). Additional FE-IV regressions are estimated using the following variables and their interaction with mobile phone ownership - geography (formal an informal parts of rural and urban areas), population group (African, Colored, Asian/Indian, White), gender (male and female), employment (with and without a job), educational attainment (no schooling, primary low and high, secondary, tertiary) and access to finance (store cards, home loan, consumer bank loans, mashonisa loans, microlender loans, remittances). Estimated results are not strong. Some estimated coefficients, statistically significant at the 15-20 percent levels, suggest African among different population groups tends to witness greater and positive consumption effects of mobile phone ownership. This could reflect the fact that the African population group represents more than 80 percent of the sample but tends to be in the relatively lower end of the consumption distribution with a higher density.

\section{SuMMARY AND DiscuSSION}

Digitalization is generating welfare benefits in South Africa. This paper studies the impact of mobile phone ownership on individual level consumption. This is the first study to assess the initial impact of ongoing digitalization in South Africa relying on rich household survey data, the National Income Dynamics Study (NIDS). The data track the same individuals across 5 waves spanning 2008-17. Another novelty is to investigate distributional effects of mobile phone ownership. Attempts are made to disentangle the two-way relationship between consumption and mobile phone ownership, which is inherently difficult. A range of macro-level conditions and micro-level individual characteristics are controlled for.

Estimated results suggest that consumption of mobile phone owners tends to be 10-20 percent above that of non-owners. Results also indicate that benefits tend to accrue more on individuals with relatively low levels of consumption, potentially as a greater number of new users, likely with greater marginal positive effects on consumption, and a faster reduction of user costs help them reap greater gains. The literature argues that mobile phone ownership facilitates greater and more affordable access to information, generating welfare gains. It enhances market efficiency, networking and starting a business, thus raising disposable income, particularly for the most vulnerable. Benefits tend to accrue more on individuals with relatively low levels of consumption, potentially as a greater number of new 
users, likely with higher marginal positive effects on consumption, and a faster rate of user cost reduction help reap greater gains.

This finding suggests that policies to promote greater inclusion of lower income consumers into digitalization could enhance welfare, particularly because the COVID-19 pandemic risks scarring economic activity and social conditions. Looking ahead, availability of additional waves of NIDS data will provide scope for solidifying the paper's findings. In pursuing digitalization, it is important to pay due attention to its implications for financial stability and inequality. In contrast to credit, other forms of access, such as basic payments and savings, do not adversely affect financial stability and can be promoted extensively until their effects on growth fade (Sahay et al. (2015)). Financial services are a powerful lever that can support a more inclusive society but, if not well managed, they can amplify inequalities (Čihák and Sahay, (2020)). Addressing the root cause of income inequality requires complementary policies, such as enhancing educational attainment, narrowing skills mismatches, or implementing redistributive fiscal policies. 


\section{REFERECES}

Aker, Jenny. 2010. "Information from Markets Near and Far: Mobile Phones and Agricultural Markets in Niger," American Economic Journal: Applied Economics, 2, 3, July, 46-59.

Aker, Jenny, and Isaac Mbiti. 2010. "Mobile Phones and Economic Development in Africa", Journal of Economic Perspectives, 24, 3, 207-32.

Alliance for Financial Inclusion. Various years and publications.

Arellano, Manuel, and Olympia Bover. 1995. "Another Look at the Instrumental Variable Estimation of Error-Components Models," Journal of Econometrics, 68, 1, July, 29-51.

Aron, J. 2018. "Mobile Money and the Economy: A Review of the Evidence," The World Bank Research Observer, 33, 135-88.

Bhavnani, A., Won-Wai Chiu, R., Janakiram, S., and Silarszky, P. 2008. "The Role of Mobile Phones in Sustainable Rural Poverty Reduction," ICT Policy Division, Global Information and Communications Department. World Bank.

Blundell, Richard, and Stephen Bond. 1998. "Initial Conditions and Moment Restrictions in Dynamic Panel Data Models," Journal of Econometrics, 87, 1, November, 115-43.

Čihák, M. and R. Sahay. 2020. Finance and Inequality. IMF Staff Discussion Note 20/01.

De Silva, H. 2005. “An Innovative Fruit and Vegetable Market Information and Price Gathering System in Sri Lanka: The Govi Gnana (Farmer Knowledge) Service.” Presented at the USAID and World Bank sponsored Workshop: Inaugurating New Partnerships in the Global Food Chain at the 15th Annual World Food and Agribusiness Forum, Symposium and Case Conference, Chicago, USA

Genesis, IFWG, SECO, and World Bank. 2019. "Fintech Scoping in South Africa."

Havemann, Roy. 2018. "Can Creditor Bain-in Trigger Contagion? The Experience of an Emerging Market." Review of Finance, 23, 6, 1155-80.

2020. "Contagion without deposit insurance: The South African small bank crisis of 2002-3." Economic Research South Africa Working Paper 823.

Independent Communications Authority of South Africa (ICASA). 2020. "The State of the ICT Sector Report in South Africa."

International Monetary Fund (IMF). 2019. "Annex VII. Fintech and Financial Inclusion in South Africa." IMF Country Report 20/33. 
Jack, W., and T. Suri. 2014. "Risk Sharing and Transactions Costs: Evidence from Kenya's Mobile Money Revolution," American Economic Review, 104, 1, January, 183-223.

Jensen, Robert. 2007. "The Digital Provide: Information (Technology), Market Performacne, and Welfare in the Southern Indian Fisheries Sector," Quarterly Journal of Ecnomics, $122,3,879-924$.

Kikulwe, Enoch, Elisabeth Fischer, and Matin Qaim. 2014. "Mobile Money, Smallholder Farmers, and Household Welfare in Kenya," PLoS ONE 9 (10): e109804.

Klonner, S., and P. Nolen. 2008. "Does ICT Benefit the Poor? Evidence from South Africa." Unpublished.

Munyegera, G. K., and T. Matsumoto. 2016. "Mobile Money, Remittances, and Household Welfare: Panel Evidence from Rural Uganda." World Development, 79, C, 127-37

2018. "ICT for Financial Access: Mobile Money and the Financial Behavior of Rural Households in Uganda," Review of Development Economics, 22, 1, 45-66.

Muto, Megumi and Takashi Yamano. 2009. “The Impact of Mobile Phone Coverage Expansion on Market Participation: Panel Data Evidence from Uganda," World Development, 37, 12, December, 1887-96.

Oyewumi, O. A. 2006. "Agricultural Market Development through Information and Communication Technology (ICT): A Developing Country Experience.” International Food and Agribusiness Management Review, 9, 2, 109-20.

Philippon, Thomas. 2020. “On Fintech and Financial Inclusion,” BIS Wokirng Paper 841.

Riley, Emma. 2018. "Mobile Money and Risk Sharing Against Village Shocks," Journal of Development Economics, 135, November, 43-58.

Roodman, David. 2009. "A Note on the Theme of Too Many Instruments," Oxford Bulletin of Economics and Statistics, 71, 1, 135-58.

2009. "How to do xtabond2: An introduction to difference and system GMM in Stata," Stata Journal, 9, November, 1, 86-136.

Sahay, R., M. Čihák, P. N'Diaye, A. Barajas, S. Mitra, A. Kyobe, Y. N. Mooi, and S. R. Yousefi. 2015. "Financial Inclusion: Can It Meet Multiple Macroeconomic Goals?" Staff Discussion Note 15/17. 
Tabetando, Rayner and Tomoya Matsumoto. 2020. "Mobile Money, Risk Sharing, and Educational Investment: Panel Evidence from Rural Uganda," Review of Development Economics, 24, 84-105.

World Bank. 2016. “Digital Dividends." World Development Report. 
ANNEX I. TABleS AND FigureS

Table A1. Determinants of Consumption in South Africa: System GMM Results

\begin{tabular}{|c|c|c|c|c|c|c|c|c|c|c|}
\hline \multicolumn{11}{|l|}{ Macro } \\
\hline Real GDP (log) & LO & $1.597^{\star * \star}$ & $1.497^{\star \star *}$ & $1.653^{\star \star *}$ & $1.451^{* * *}$ & $1.574^{\star \star *}$ & $1.606^{\star \star \star}$ & $1.554^{\star * \star}$ & $1.501^{\star \star *}$ & $1.584^{\star \star \star}$ \\
\hline Real policy rate & LO & $-0.047^{* * *}$ & $-0.041^{\star * *}$ & $-0.045^{\star * *}$ & $-0.053^{* * *}$ & $-0.045^{\star * *}$ & $-0.049 * * *$ & $-0.045^{* * *}$ & $-0.039^{* * *}$ & $-0.043^{\star \star \star}$ \\
\hline \multicolumn{11}{|l|}{ Micro } \\
\hline Owns a mobile phone & L1 & 0.159 & $0.307^{\star \star}$ & $0.192^{*}$ & $0.280^{\star *}$ & 0.242 & $0.239 * *$ & 0.149 & $0.359^{\star *}$ & $0.203^{*}$ \\
\hline Employed & L1 & 0.057 & 0.345 & 0.145 & 0.018 & 0.314 & 0.086 & 0.078 & 0.38 & 0.158 \\
\hline \multicolumn{11}{|l|}{ Education } \\
\hline No schooling & L1 & 0.074 & $-1.620^{* * *}$ & -0.313 & 0.153 & $-1.610^{* * *}$ & -0.278 & 0.115 & $-1.631^{* * *}$ & -0.286 \\
\hline Primary, lower & L1 & -0.482 & -0.216 & -0.392 & -0.438 & -0.239 & -0.336 & -0.525 & -0.191 & $-0.414^{*}$ \\
\hline Primary, higher & L1 & -0.215 & $-1.282^{* * *}$ & $-0.321^{*}$ & -0.1 & $-1.282^{\star * *}$ & -0.261 & -0.238 & $-1.282^{* * *}$ & $-0.326^{*}$ \\
\hline Secondary & L1 & -0.079 & $-0.588^{* \star *}$ & -0.125 & -0.056 & $-0.589 * * *$ & -0.09 & -0.076 & $-0.587^{\star * *}$ & -0.117 \\
\hline Tertiary & L1 & $\ldots$ & $\ldots$ & $\ldots$ & $\ldots$ & $\ldots$ & $\ldots$ & $\ldots$ & $\ldots$ & $\ldots$ \\
\hline \multicolumn{11}{|l|}{ Other } \\
\hline Real consumption (log) & L1 & $0.603^{* * *}$ & 0.182 & $0.476^{\star \star \star}$ & $0.634^{* * *}$ & 0.203 & $0.526^{\star * \star}$ & $0.595^{\star * \star}$ & 0.161 & $0.476^{\star \star \star}$ \\
\hline Constant & $\ldots$ & Y & Y & Y & Y & Y & Y & Y & Y & Y \\
\hline \# of Obs. & & 21,716 & 21,716 & 21,716 & 21,716 & 21,716 & 21,716 & 21,716 & 21,716 & 21,716 \\
\hline Cross section $(\mathrm{N})$ & & 5,429 & 5,429 & 5,429 & 5,429 & 5,429 & 5,429 & 5,429 & 5,429 & 5,429 \\
\hline Time series $(T)$ & & 4 & 4 & 4 & 4 & 4 & 4 & 4 & 4 & 4 \\
\hline $\operatorname{ar1}$ & & 0 & 0 & 0 & 0 & 0 & 0 & 0 & 0 & 0 \\
\hline ar2 & & 0.001 & 0.275 & 0 & 0 & 0.228 & 0 & 0.001 & 0.322 & 0 \\
\hline hansen & & 0.358 & 0.343 & 0.04 & 0.855 & 0.358 & 0.288 & 0.131 & 0.325 & 0.011 \\
\hline gmm lag & & 2,2 & 3,3 & 2,3 & 2,2 & 3,3 & 2,3 & 2,2 & 3,3 & 2,3 \\
\hline gmm equation & & both & both & both & both & both & both & both & both & both \\
\hline iv equation & & both & both & both & level & level & level & diff & diff & diff \\
\hline
\end{tabular}

Sources: Haver, NIDS, and author's calculations.

Note: Dependent variable is individual level real expenditure in log. L0 and L1 signify contemporaneous value and one period lag. ${ }^{* *},{ }^{* *}$, and ${ }^{*}$ when statistically significant at the 1,5 , and 10 percent levels. 


\begin{tabular}{|c|c|c|c|c|c|c|}
\hline & & Geography & Population group & Gender & Employment & Education \\
\hline \multicolumn{7}{|l|}{ Macro } \\
\hline Real GDP (log) & LO & $3.693^{\star \star *}$ & $3.661^{\star \star \star}$ & $3.671^{* * *}$ & $3.671^{* * *}$ & $3.676^{\star * *}$ \\
\hline Real policy rate & LO & 0.003 & 0.004 & 0.003 & 0.004 & 0.004 \\
\hline \multicolumn{7}{|l|}{ Micro } \\
\hline Owns a mobile phone & L1 & -0.045 & -0.257 & -0.004 & 0.010 & -0.341 \\
\hline Employed & L1 & -0.007 & -0.007 & -0.008 & 0.014 & -0.008 \\
\hline Receives grants & $\mathrm{L} 1$ & -0.034 & -0.033 & -0.033 & -0.033 & -0.035 \\
\hline \multicolumn{7}{|l|}{ Education } \\
\hline No schooling & L1 & -0.115 & -0.127 & -0.128 & -0.126 & -0.446 \\
\hline Primary, lower & L1 & $-0.162^{\star *}$ & $-0.173^{*}$ & $-0.173^{*}$ & $-0.171^{*}$ & -0.512 \\
\hline Primary, higher & $\mathrm{L} 1$ & $-0.147^{\star \star}$ & $-0.157^{*}$ & $-0.157^{*}$ & $-0.155^{\star}$ & -0.528 \\
\hline Secondary & L1 & $-0.066^{*}$ & $-0.069^{*}$ & $-0.069^{*}$ & $-0.069^{*}$ & -0.369 \\
\hline Tertiary & L1 & & $\ldots$ & $\ldots$ & $\ldots$ & $\ldots$ \\
\hline \multicolumn{7}{|l|}{ Geography } \\
\hline Rural, formal & L1 & 0.036 & 0.040 & 0.040 & 0.040 & 0.038 \\
\hline Rural, informal & L1 & $-0.612^{* * *}$ & $-0.614^{\star \star *}$ & $-0.614^{\star \star \star}$ & $-0.614^{\star \star *}$ & $-0.614^{\star \star *}$ \\
\hline Urban, formal & L1 & $0.121^{\star}$ & $0.120^{*}$ & $0.120^{\star}$ & $0.119^{\star}$ & $0.119^{\star}$ \\
\hline Urban, informal & L1 & $\ldots$ & $\ldots$ & $\ldots$ & $\ldots$ & $\ldots$ \\
\hline \multicolumn{7}{|l|}{$\begin{array}{l}\text { Interaction with mobile } \\
\text { phone ownership }\end{array}$} \\
\hline Rural, formal & L1 & -0.109 & $\ldots$ & $\ldots$ & $\ldots$ & $\ldots$ \\
\hline Rural, informal & $\mathrm{L} 1$ & 0.132 & $\ldots$ & $\ldots$ & $\ldots$ & $\ldots$ \\
\hline Urban, formal & L1 & -0.172 & $\ldots$ & $\ldots$ & $\ldots$ & $\ldots$ \\
\hline Urban, informal & L1 & $\ldots$ & $\ldots$ & $\ldots$ & $\ldots$ & $\ldots$ \\
\hline African & $\mathrm{L} 1$ & $\ldots$ & 0.260 & $\ldots$ & $\ldots$ & $\ldots$ \\
\hline Asian/Indian & L1 & $\ldots$ & 0.387 & $\ldots$ & $\ldots$ & $\ldots$ \\
\hline Colored & L1 & $\ldots$ & $\ldots$ & $\ldots$ & $\ldots$ & $\ldots$ \\
\hline White & L1 & $\ldots$ & $\ldots$ & $\ldots$ & $\ldots$ & $\ldots$ \\
\hline Female & L1 & $\ldots$ & $\ldots$ & 0.038 & $\ldots$ & $\ldots$ \\
\hline Employed & L1 & $\ldots$ & $\ldots$ & $\ldots$ & -0.025 & $\ldots$ \\
\hline No schooling & $\mathrm{L} 1$ & $\ldots$ & $\ldots$ & $\ldots$ & $\ldots$ & 0.348 \\
\hline Primary, lower & L1 & $\ldots$ & $\ldots$ & $\ldots$ & $\ldots$ & 0.372 \\
\hline Primary, higher & & $\ldots$ & $\ldots$ & $\ldots$ & $\ldots$ & 0.409 \\
\hline Secondary & & $\ldots$ & $\ldots$ & $\ldots$ & $\ldots$ & 0.310 \\
\hline Tertiary & & $\ldots$ & $\ldots$ & $\ldots$ & $\ldots$ & $\ldots$ \\
\hline \multicolumn{7}{|l|}{ Other } \\
\hline Real consumption (log) & L1 & $-0.192^{\star \star *}$ & $-0.193^{\star * *}$ & $-0.192^{\star \star \star}$ & $-0.192^{\star \star *}$ & $-0.193^{\star \star *}$ \\
\hline Geography * GDP & L1 & Y & Y & Y & Y & Y \\
\hline Weights & $\ldots$ & Y & Y & Y & Y & Y \\
\hline Individual effects & $\ldots$ & Y & Y & Y & Y & Y \\
\hline Constant & $\ldots$ & Y & Y & Y & Y & Y \\
\hline \# of Obs. & & 16264.000 & 16264.000 & 16264.000 & 16264.000 & 16264.000 \\
\hline Cross section (N) & & 5421.333 & 5421.333 & 5421.333 & 5421.333 & 5421.333 \\
\hline Time series $(T)$ & & 3.000 & 3.000 & 3.000 & 3.000 & 3.000 \\
\hline Adjusted R2 & & 0.147 & 0.146 & 0.146 & 0.146 & 0.147 \\
\hline
\end{tabular}




\begin{tabular}{|c|c|c|c|c|c|c|c|c|c|c|c|c|c|}
\hline & & \multicolumn{6}{|c|}{ With AR(1) } & \multicolumn{6}{|c|}{ No $A R(1)$} \\
\hline & & Store card & Home loan & $\begin{array}{l}\text { Personal bank } \\
\text { loan }\end{array}$ & Microlender & Mashonisa & Remittances & Store card & Home loan & $\begin{array}{l}\text { Personal bank } \\
\text { loan }\end{array}$ & Microlender & Mashonisa & Remittances \\
\hline \multicolumn{14}{|l|}{ Macro } \\
\hline Real GDP (log) & LO & $3.751^{1 \star \star *}$ & $3.760^{* \star \star}$ & $3.760^{* \star \star *}$ & $3.743^{\star \star \star *}$ & $3.747^{\star \star \star *}$ & $3.754^{* \star *}$ & $3.560^{* \star \star *}$ & $3.553^{* \star *}$ & $3.562^{* * \star}$ & $3.533^{* * *}$ & $3.539^{* * *}$ & $3.553^{* \star \star}$ \\
\hline Real policy rate & LO & -0.005 & -0.005 & -0.004 & -0.004 & -0.005 & -0.005 & -0.019 & -0.020 & -0.019 & -0.019 & -0.020 & -0.019 \\
\hline \multicolumn{14}{|l|}{ Micro } \\
\hline Owns a mobile phone & L1 & $0.156^{\star \star}$ & $0.154^{\star \star}$ & $0.156^{\star \star}$ & $0.153^{* *}$ & $0.154^{\star \star}$ & $0.147^{* *}$ & $0.153^{\star \star}$ & $0.151^{\star \star}$ & $0.153^{\star \star}$ & $0.150^{\star \star}$ & $0.152^{\star \star}$ & $0.145^{\star \star}$ \\
\hline Employed & L1 & -0.004 & -0.003 & -0.003 & -0.003 & -0.003 & -0.003 & $-0.042^{\star \star}$ & $-0.043^{\star \star}$ & $-0.042^{\star \star}$ & $-0.043^{\star \star}$ & $-0.043^{\star \star}$ & $-0.043^{\star \star}$ \\
\hline Receives grants & L1 & -0.032 & -0.033 & -0.033 & -0.033 & -0.032 & -0.032 & -0.001 & -0.001 & -0.001 & -0.001 & 0.000 & 0.001 \\
\hline \multicolumn{14}{|l|}{ Education } \\
\hline No schooling & L1 & -0.004 & -0.003 & -0.003 & -0.003 & -0.003 & -0.003 & $-0.042^{\star \star}$ & $-0.043^{\star \star}$ & $-0.042^{\star \star}$ & $-0.043^{* *}$ & $-0.043^{* *}$ & $-0.043^{\star *}$ \\
\hline Primary, lower & L1 & $-0.152^{\star}$ & $-0.152^{\star}$ & $-0.152^{\star}$ & $-0.151^{\star}$ & $-0.152^{\star}$ & $-0.150^{\star}$ & -0.131 & -0.128 & -0.127 & -0.128 & -0.128 & -0.128 \\
\hline Primary, higher & L1 & $-0.169^{\star}$ & $-0.170^{*}$ & $-0.169^{*}$ & $-0.169^{*}$ & $-0.168^{\star}$ & $-0.168^{\star}$ & $-0.160^{*}$ & $-0.158^{\star}$ & $-0.158^{*}$ & $-0.157^{*}$ & $-0.156^{*}$ & $-0.158^{*}$ \\
\hline Secondary & L1 & $-0.068^{*}$ & $-0.068^{\star}$ & $-0.068^{\star}$ & $-0.068^{\star}$ & $-0.068^{*}$ & $-0.067^{\star}$ & -0.044 & -0.041 & -0.041 & -0.040 & -0.041 & -0.041 \\
\hline \multirow{2}{*}{\multicolumn{14}{|c|}{ Geography }} \\
\hline & & & & & & & & & & & & & \\
\hline Rural, formal & L1 & 0.041 & 0.040 & 0.041 & 0.041 & 0.041 & 0.041 & 0.031 & 0.028 & 0.030 & 0.030 & 0.030 & 0.030 \\
\hline Rural, informal & L1 & $-0.607^{\star * \star}$ & $-0.607 * \star * \star 1$ & $-0.607^{\star \star \star *}$ & $-0.606^{\star \star \star}$ & $-0.607^{\star \star \star}$ & $-0.607^{\star \star \star *}$ & $-0.611^{\star \star \star}$ & $-0.612^{\star \star \star}$ & $-0.612^{\star \star \star}$ & $-0.611^{\star \star \star}$ & $-0.611^{\star \star \star}$ & $-0.613^{\star \star \star *}$ \\
\hline Urban, formal & L1 & $0.120^{*}$ & $0.121^{\star}$ & $0.121^{\star}$ & $0.122^{\star}$ & $0.121^{\star}$ & $0.121^{\star}$ & $0.118^{\star}$ & $0.116^{*}$ & $0.116^{*}$ & $0.117^{\star}$ & $0.116^{*}$ & $0.115^{*}$ \\
\hline \multirow{2}{*}{\multicolumn{14}{|c|}{ Access to finance }} \\
\hline & & & & & & & & & & & & & \\
\hline Store card & L1 & 0.046 & $\ldots$ & $\ldots$ & $\ldots$ & $\ldots$ & $\ldots$ & 0.039 & $\ldots$ & $\ldots$ & $\ldots$ & $\ldots$ & $\ldots$ \\
\hline Home loan & L1 & $\ldots$ & 0.089 & $\ldots$ & $\ldots$ & $\ldots$ & $\ldots$ & $\ldots$ & 0.087 & $\ldots$ & $\ldots$ & $\ldots$ & $\ldots$ \\
\hline Personal bank loan & L1 & $\ldots$ & $\ldots$ & 0.069 & $\ldots$ & $\ldots$ & $\ldots$ & $\ldots$ & $\ldots$ & 0.057 & $\ldots$ & $\ldots$ & $\ldots$ \\
\hline Microlender & L1 & $\ldots$ & & & -0.027 & & & $\ldots$ & $\ldots$ & & -0.082 & & \\
\hline Mashonisa & L1 & $\ldots$ & $\ldots$ & $\ldots$ & $\ldots$ & 0.010 & $\ldots$ & $\ldots$ & $\ldots$ & $\ldots$ & $\ldots$ & 0.000 & $\ldots$ \\
\hline \multirow{2}{*}{\multicolumn{14}{|c|}{$\begin{array}{l}\text { Interaction with mobile } \\
\text { phone ownership }\end{array}$}} \\
\hline & & & & & & & & & & & & & \\
\hline Store card & L1 & -0.044 & $\ldots$ & $\ldots$ & $\ldots$ & $\ldots$ & $\ldots$ & -0.066 & $\ldots$ & $\ldots$ & $\ldots$ & ... & $\ldots$ \\
\hline Home loan & L1 & $\ldots$ & -0.112 & $\ldots$ & $\ldots$ & $\ldots$ & $\ldots$ & $\ldots$ & -0.114 & $\ldots$ & $\ldots$ & $\ldots$ & $\ldots$ \\
\hline Personal bank loan & L1 & $\ldots$ & $\ldots$ & -0.096 & $\ldots$ & $\ldots$ & $\ldots$ & $\ldots$ & $\ldots$ & -0.101 & $\ldots$ & $\ldots$ & $\ldots$ \\
\hline Microlender & L1 & $\ldots$ & $\ldots$ & $\ldots$ & 0.101 & $\ldots$ & $\ldots$ & $\ldots$ & $\ldots$ & $\ldots$ & 0.052 & $\ldots$ & ... \\
\hline Mashonisa & L1 & $\ldots$ & $\ldots$ & $\ldots$ & $\ldots$ & -0.064 & $\ldots$ & $\ldots$ & $\ldots$ & $\ldots$ & $\ldots$ & -0.069 & $\ldots$ \\
\hline Remittances & L1 & ... & $\ldots$ & $\ldots$ & $\ldots$ & $\ldots$ & 0.053 & $\ldots$ & $\ldots$ & $\ldots$ & $\ldots$ & $\ldots$ & 0.042 \\
\hline \multicolumn{14}{|c|}{ Other } \\
\hline Real consumption (log) & L1 & $-0.193^{\star \star \star *}$ & $-0.193^{* \star *}$ & $-0.192^{\star \star *}$ & $-0.193^{* \star *}$ & $-0.192^{* \star *}$ & $-0.193^{* \star *}$ & $\ldots$ & $\ldots$ & $\ldots$ & $\ldots$ & $\ldots$ & $\ldots$ \\
\hline Geography * GDP & L1 & Y & Y & Y & Y & Y & Y & $\mathrm{Y}$ & Y & Y & Y & Y & Y \\
\hline Weights & $\ldots$ & Y & Y & Y & Y & Y & Y & Y & Y & Y & Y & Y & Y \\
\hline Individual effects & $\ldots$ & Y & Y & Y & y & y & y & Y & Y & Y & Y & y & Y \\
\hline Constant & $\ldots$ & y & y & y & y & y & y & Y & Y & Y & y & Y & Y \\
\hline \# of Obs. & & 16287 & 16287 & 16287 & 16287 & 16287 & 16287 & 16287 & 16287 & 16287 & 16287 & 16287 & 16287 \\
\hline Cross section (N) & & 5429 & 5429 & 5429 & 5429 & 5429 & 5429 & 5429 & 5429 & 5429 & 5429 & 5429 & 5429 \\
\hline Time series (T) & & 3 & 3 & 3 & 3 & 3 & 3 & 3 & 3 & 3 & 3 & 3 & 3 \\
\hline Adjusted R2 & & 0.146 & 0.146 & 0.146 & 0.147 & 0.146 & 0.146 & 0.112 & 0.112 & 0.112 & 0.112 & 0.112 & 0.112 \\
\hline
\end{tabular}


Figure A1. South Africa: Private Consumption

Per-Capita Real Private Consumption (2014=100)

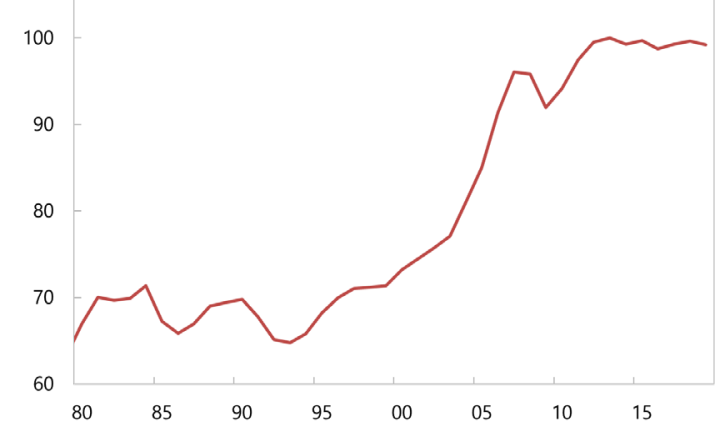

Private Consumption (Percent of GDP)

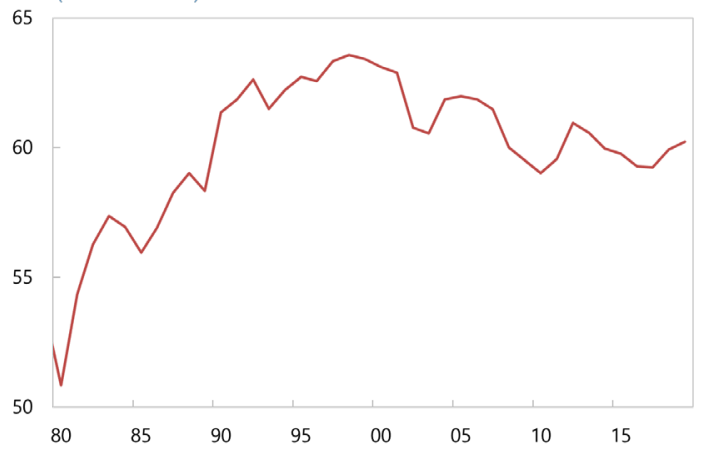

Sources: Haver and author's calculations.

Note: 2019 value is estimated by the author.

\section{Figure A2. Selected Labor Market Characteristics}
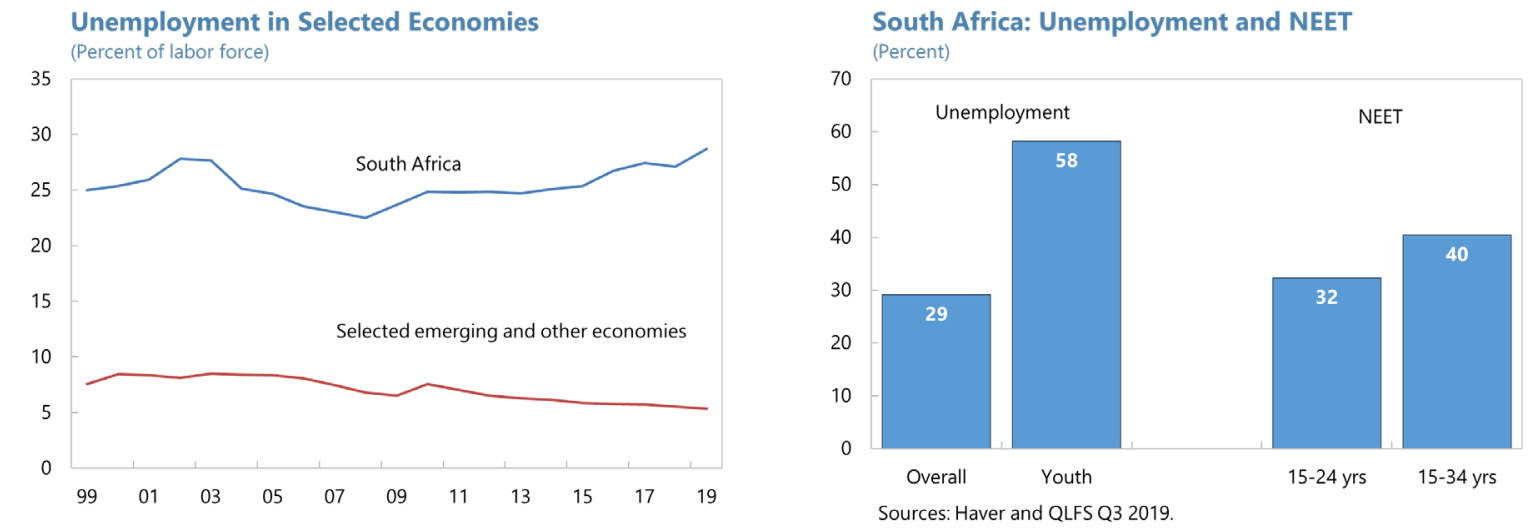

Sources: Haver, Quarterly Labor Force Survey South Africa Q3 2019, WDI, and author's calculations. Note: NEET stands for Not in Employment, Education, or Training.

Figure A3. Indicators of Income Inequality
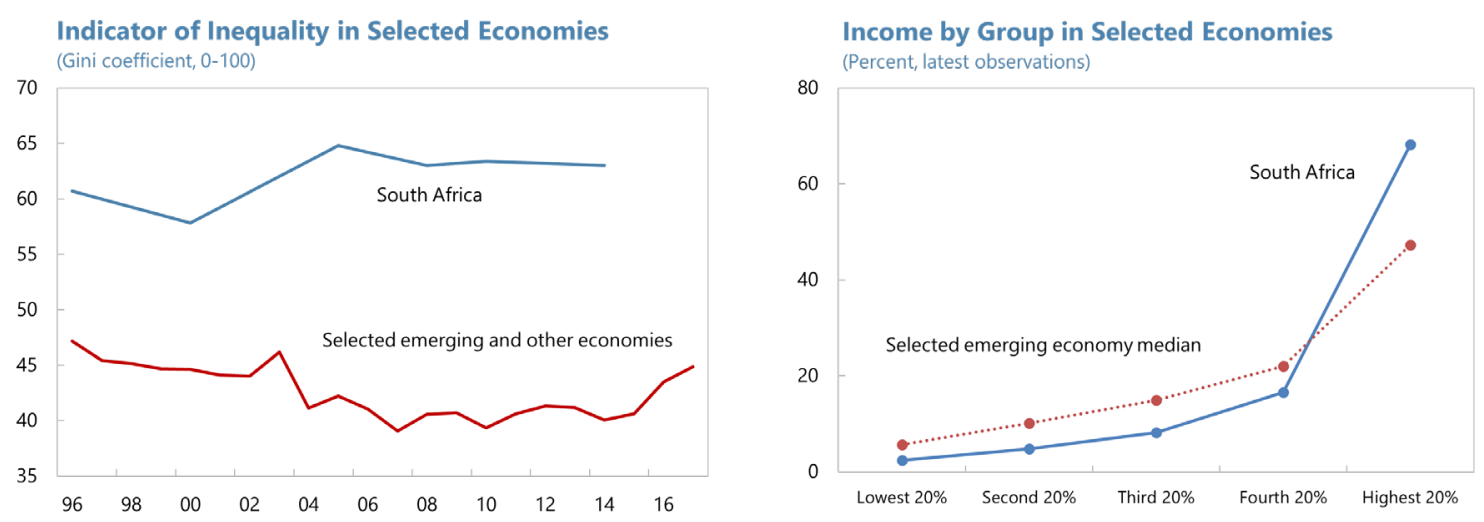

Sources: WDI, World Bank Poverty and Equity Data, and author's calculations. 
Figure A4. South Africa: Grants
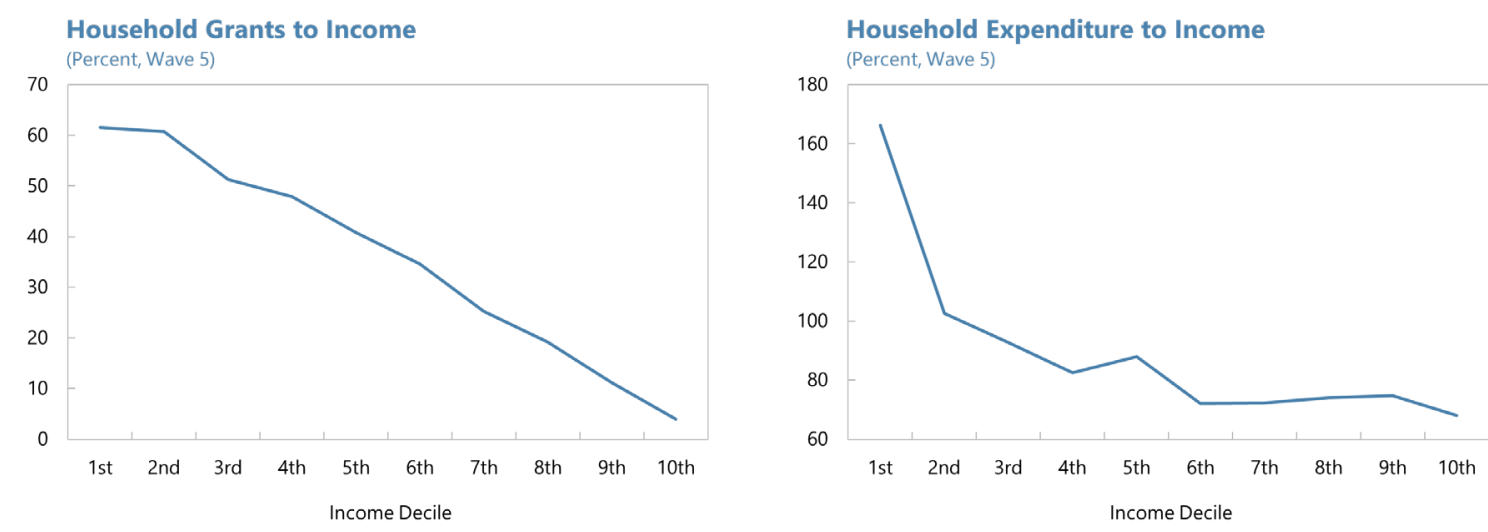

Sources: NIDS, and author's calculations. 